\title{
Syntheses, structures, and stabilities of aliphatic and aromatic fluorous iodine(I) and iodine(III) compounds: the role of iodine Lewis basicity
}

\author{
Tathagata Mukherjee ${ }^{1, \S}$, Soumik Biswas ${ }^{1}$, Andreas Ehnbom ${ }^{1}$, Subrata K. Ghosh ${ }^{1}$, \\ Ibrahim El-Zoghbi ${ }^{2}$, Nattamai Bhuvanesh ${ }^{1}$, Hassan S. Bazzi ${ }^{* 2}$ and John A. Gladysz ${ }^{* 1}$
}

\section{Full Research Paper}

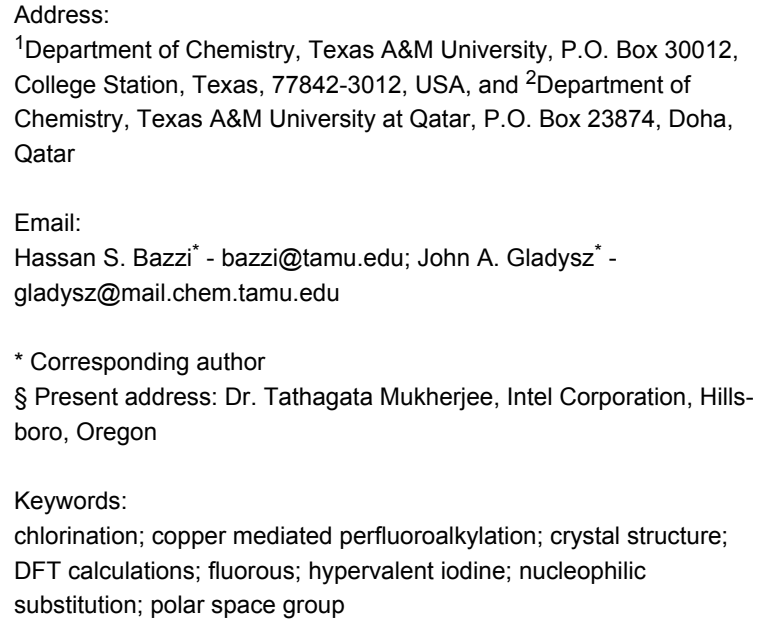

Keywords:

chlorination; copper mediated perfluoroalkylation; crystal structure;

DFT calculations; fluorous; hypervalent iodine; nucleophilic

substitution; polar space group

\author{
Beilstein J. Org. Chem. 2017, 13, 2486-2501. \\ doi:10.3762/bjoc. 13.246
}

Received: 23 August 2017

Accepted: 25 October 2017

Published: 23 November 2017

This article is part of the Thematic Series "Organo-fluorine chemistry IV".

Guest Editor: D. O'Hagan

(c) 2017 Mukherjee et al.; licensee Beilstein-Institut.

License and terms: see end of document.

\begin{abstract}
The title molecules are sought in connection with various synthetic applications. The aliphatic fluorous alcohols $\mathrm{R}_{\mathrm{f} n} \mathrm{CH}_{2} \mathrm{OH}$ $\left(\mathrm{R}_{\mathrm{f} n}=\mathrm{CF}_{3}\left(\mathrm{CF}_{2}\right)_{n-1} ; n=11,13,15\right)$ are converted to the triflates $\mathrm{R}_{\mathrm{f} n} \mathrm{CH}_{2} \mathrm{OTf}\left(\mathrm{Tf}_{2} \mathrm{O}\right.$, pyridine; 22-61\%) and then to $\mathrm{R}_{\mathrm{f} n} \mathrm{CH}_{2} \mathrm{I}(\mathrm{NaI}$, acetone; $58-69 \%$ ). Subsequent reactions with $\mathrm{NaOCl} / \mathrm{HCl}$ give iodine(III) dichlorides $\mathrm{R}_{\mathrm{f} n} \mathrm{CH}_{2} \mathrm{ICl}_{2}(n=11,13 ; 33-81 \%)$, which slowly evolve $\mathrm{Cl}_{2}$. The ethereal fluorous alcohols $\mathrm{CF}_{3} \mathrm{CF}_{2} \mathrm{CF}_{2} \mathrm{O}\left(\mathrm{CF}\left(\mathrm{CF}_{3}\right) \mathrm{CF}_{2} \mathrm{O}\right)_{x} \mathrm{CF}\left(\mathrm{CF}_{3}\right) \mathrm{CH}_{2} \mathrm{OH}(x=2-5)$ are similarly converted to triflates and then to iodides, but efforts to generate the corresponding dichlorides fail. Substrates lacking a methylene group, $\mathrm{R}_{\mathrm{f} n} \mathrm{I}$, are also inert, but additions of TMSCl to bis(trifluoroacetates) $\mathrm{R}_{\mathrm{fn}} \mathrm{I}\left(\mathrm{OCOCF}_{3}\right)_{2}$ appear to generate $\mathrm{R}_{\mathrm{f} n} \mathrm{ICl}_{2}$, which rapidly evolve $\mathrm{Cl}_{2}$. The aromatic fluorous iodides $1,3-\mathrm{R}_{\mathrm{f} 6} \mathrm{C}_{6} \mathrm{H}_{4} \mathrm{I}, 1,4-\mathrm{R}_{\mathrm{f} 6} \mathrm{C}_{6} \mathrm{H}_{4} \mathrm{I}$, and 1,3- $\mathrm{R}_{\mathrm{f} 10} \mathrm{C}_{6} \mathrm{H}_{4} \mathrm{I}$ are prepared from the corresponding diiodides, copper, and $\mathrm{R}_{\mathrm{f} n} \mathrm{I}\left(110-130{ }^{\circ} \mathrm{C}, 50-60 \%\right)$, and afford quite stable $\mathrm{R}_{\mathrm{f} n} \mathrm{C}_{6} \mathrm{H}_{4} \mathrm{ICl}_{2}$ species upon reaction with $\mathrm{NaOCl} / \mathrm{HCl}(80-89 \%)$. Iodinations of 1,3- $\left(\mathrm{R}_{\mathrm{f} 6}\right)_{2} \mathrm{C}_{6} \mathrm{H}_{4}$ and 1,3- $\left(\mathrm{R}_{\mathrm{f} 8} \mathrm{CH}_{2} \mathrm{CH}_{2}\right)_{2} \mathrm{C}_{6} \mathrm{H}_{4}$ (NIS or $\left.\mathrm{I}_{2} / \mathrm{H}_{5} \mathrm{IO}_{6}\right)$ give $1,3,5-\left(\mathrm{R}_{\mathrm{f} 6}\right)_{2} \mathrm{C}_{6} \mathrm{H}_{3} \mathrm{I}$ and $1,2,4-$ $\left(\mathrm{R}_{\mathrm{f} 8} \mathrm{CH}_{2} \mathrm{CH}_{2}\right)_{2} \mathrm{C}_{6} \mathrm{H}_{3} \mathrm{I}(77-93 \%)$. The former, the crystal structure of which is determined, reacts with $\mathrm{Cl}_{2}$ to give a $75: 25 \mathrm{ArICl} 2 / \mathrm{ArI}$ mixture, but partial $\mathrm{Cl}_{2}$ evolution occurs upon work-up. The latter gives the easily isolated dichloride 1,2,4- $\left(\mathrm{R}_{\mathrm{f} 8} \mathrm{CH}_{2} \mathrm{CH}_{2}\right)_{2} \mathrm{C}_{6} \mathrm{H}_{3} \mathrm{ICl} 2$ $(89 \%)$. The relative thermodynamic ease of dichlorination of these and other iodine(I) compounds is probed by DFT calculations.
\end{abstract}




\section{Introduction}

A number of fluorous alkyl iodides, usually of the formula $\mathrm{R}_{\mathrm{f} n} \mathrm{CH}_{2} \mathrm{CH}_{2} \mathrm{I}$ or $\mathrm{R}_{\mathrm{f} n} \mathrm{I}\left(\mathrm{R}_{\mathrm{f} n}=\mathrm{CF}_{3}\left(\mathrm{CF}_{2}\right)_{n-1}\right)$, are commercially available and have seen abundant use as building blocks in fluorous chemistry [1-3]. Fluorous aryl iodides, such as $\mathrm{R}_{\mathrm{fn}} \mathrm{C}_{6} \mathrm{H}_{4} \mathrm{I}$ or $\mathrm{R}_{\mathrm{f} n}\left(\mathrm{CH}_{2}\right)_{m} \mathrm{C}_{6} \mathrm{H}_{4} \mathrm{I}$ species, are also often employed as intermediates (typically $m=2,3$ and $n \geq 6$ [1-3]), but only a few have been commercialized [4]. Many research groups have described the syntheses of other types of fluorous alkyl [5-8] and aryl [9-12] iodides [13-17]. The former are ubiquitous by virtue of the large number of perfluoroalkyl iodides $\mathrm{R}_{\mathrm{f} n} \mathrm{I}$ that have been shown to undergo free radical additions to alkenes $[7,8]$.

In previous papers, we have reported convenient preparations of a variety of fluorous alkyl iodides [13-15], aryl iodides [16,17], and hypervalent iodine(III) derivatives [16-19]. The latter have included aliphatic iodine(III) bis(trifluoroacetates) [18,19] and dichlorides [17], and aromatic iodine(III) bis(acetates) [16] and dichlorides [17]. The bis(carboxylates) have been employed as recyclable reagents for oxidations of organic substrates $[16,18,19]$, and some of the dichlorides are depicted in Scheme 1. Others have described additional fluorous iodine(III) species [11,20-22].

Recently, our attention has been directed at two potential applications of iodine containing fluorous compounds. One involves new approaches to phosphorus-carbon bond formation using fluorous alkyl and aryl iodides [23,24]. The other involves the use of fluorous iodine(III) dichlorides for free radical chlorinations [25]. In this regard, phenyl iodine(III) dichloride $\left(\mathrm{PhICl}_{2}\right)$ is an effective free radical chlorinating agent for hydrocarbons $[26,27]$. Importantly, the mechanism does not involve the liberation of $\mathrm{Cl}_{2}$, followed by the textbook sequence of steps. Rather, hydrogen abstraction is effected by a species other than the chlorine radical $\mathrm{Cl}$, presumably $\mathrm{PhICl} \cdot[26,27]$.

One potential attraction of fluorous iodine(III) dichlorides as chlorinating agents would be the recovery and recycling of the fluorous iodide byproduct. Towards this end, higher fluorophilicities are usually advantageous. To a first approximation, these are maximized by increasing the lengths and quantities of the $\left(\mathrm{CF}_{2}\right)_{n}$ segments, and decreasing the lengths and quantities of any $\left(\mathrm{CH}_{2}\right)_{m}$ segments [1-3]. However, longer $\left(\mathrm{CF}_{2}\right)_{n}$ segments are often coupled with lower absolute solubilities [1,28], a logical consequence as one approaches the macromolecular limit of polytetrafluoroethylene. Fluorophilicities are typically quantified by fluorous/organic liquid/liquid phase partition coefficients [1-3]. The most common solvent combination is perfluoro(methylcyclohexane) $\left(\mathrm{CF}_{3} \mathrm{C}_{6} \mathrm{~F}_{11}\right)$ and toluene.

The objective of this study was to bridge several strategic gaps regarding highly fluorophilic building blocks for the formation of (1) phosphorus-carbon bonded species, and (2) iodine(III) dichloride reagents. For example, aliphatic species of the formula $\mathrm{R}_{\mathrm{f} n} \mathrm{CH}_{2} \mathrm{CH}_{2} \mathrm{ICl}_{2}$ are unstable [17]. However, analogs with one less methylene group, $\mathrm{R}_{\mathrm{f} n} \mathrm{CH}_{2} \mathrm{ICl}_{2}$, have been isolated for $n=8$ and 10 as depicted in Scheme 1 [17,20]. Although partition coefficients are not available for the iodide $\mathrm{R}_{\mathrm{f} 8} \mathrm{CH}_{2} \mathrm{I}$ (the byproduct that would form in most chlorination reactions),

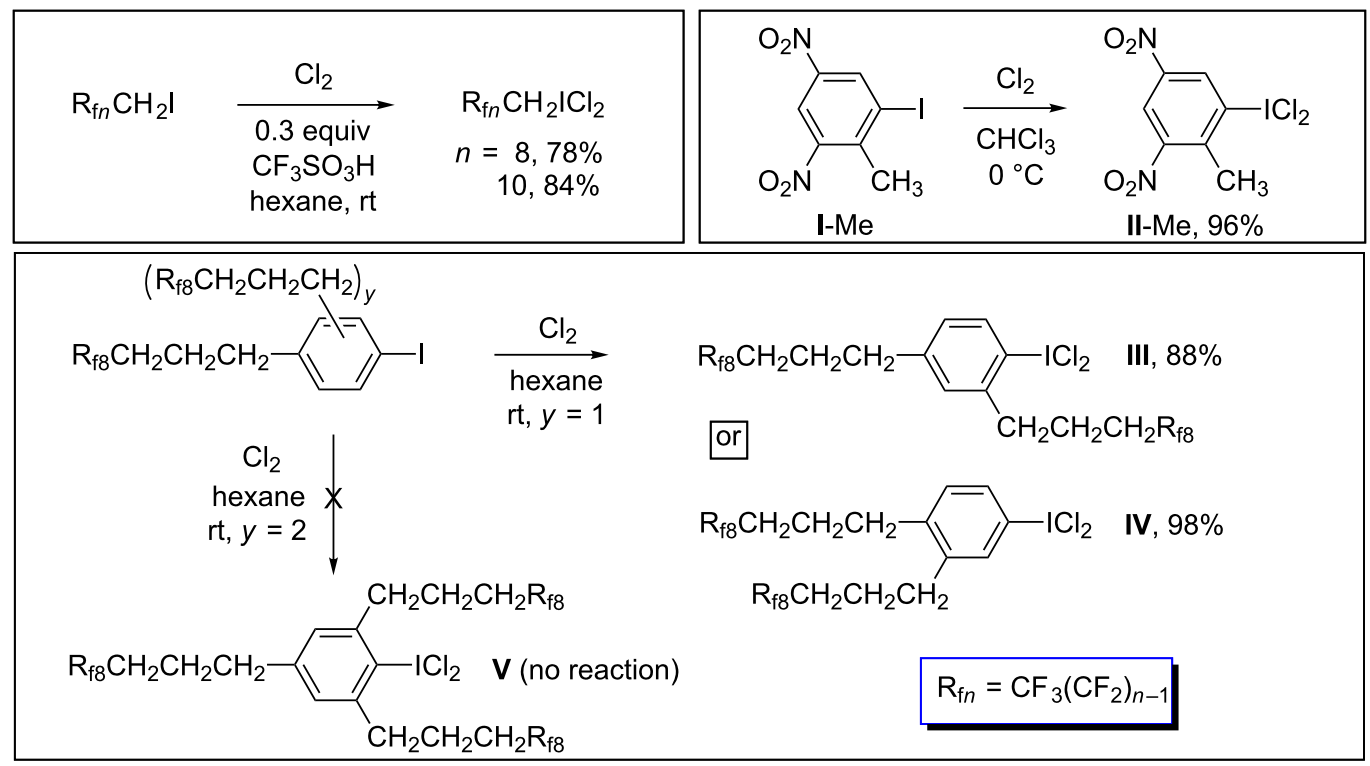


they would fall between those of $\mathrm{R}_{\mathrm{f8}} \mathrm{I}$ (88.5:11.5 for $\mathrm{CF}_{3} \mathrm{C}_{6} \mathrm{~F}_{11}$ / toluene [29]) and $\mathrm{R}_{\mathrm{f} 8}\left(\mathrm{CH}_{2}\right)_{3} \mathrm{I}(50.7: 49.3$ [30]). These rather modest fluorophilicities would presumably be lower for the more polar dichlorides $\mathrm{R}_{\mathrm{f} n} \mathrm{CH}_{2} \mathrm{ICl}_{2}$ - a possible disadvantage for reactions in fluorous solvents. In any case, higher homologs that would have more biased partition coefficients were sought.

In the same vein, literature data prompted interest in certain fluorous aromatic iodine(III) dichlorides. For example, the nonfluorous iodine(III) dichloride II-Me (Scheme 1) [31], which features two strongly electron-withdrawing nitro groups and a mildly electron-donating methyl group, is easily isolated in analytically pure form from the reaction of the corresponding aryl iodide and $\mathrm{Cl}_{2}$, even though the nitro groups render the iodine atom less Lewis basic and thermodynamically less prone to oxidation. The Hammett $\sigma$ values associated with $\mathrm{CF}_{2} \mathrm{CF}_{3}$ and $\mathrm{CF}_{2} \mathrm{CF}_{2} \mathrm{CF}_{3}$ substituents $\left(\sigma_{\mathrm{p}} 0.52 ; \sigma_{\mathrm{m}} 0.47-0.52\right.$ [32]) suggest that $\mathrm{R}_{\mathrm{f} n}$ groups are less electron withdrawing than nitro groups $\left(\sigma_{\mathrm{p}} 0.81 ; \sigma_{\mathrm{m}} 0.71\right)$. Therefore, similar fluorous compounds of the formula $\left(\mathrm{R}_{\mathrm{f} n}\right)_{2} \mathrm{C}_{6} \mathrm{H}_{3} \mathrm{ICl}_{2}$ were seen as realistic targets. The less fluorophilic homologs III and IV (Scheme 1), which feature three methylene or $\mathrm{CH}_{2} \mathrm{CH}_{2} \mathrm{CH}_{2}$ "spacers" that electronically insulate the arene ring from the perfluoroalkyl groups, have been previously isolated [17].

As described below, the pursuit of the preceding objectives has met with both success and some unanticipated speed bumps, for which parallel computational studies have provided valuable insight. Regardless, these efforts have resulted in a number of practical preparations that will soon be utilized in further applications [23], and defined various physical properties and stability limits that are useful guides for future research.

\section{Results}

Syntheses and reactions, $\mathbf{R}_{\mathrm{f} n} \mathrm{CH}_{2} \mathrm{I}(\boldsymbol{n}=11,13,15)$. To the authors' knowledge, no fluorous alkyl iodides of the formula $\mathrm{R}_{\mathrm{f} n} \mathrm{CH}_{2} \mathrm{I}$ are commercially available. Thus, as shown in Scheme 2, a sequence previously employed for lower homologs ( $n=8,10$ [13]) was investigated. The commercially available alcohols $\mathrm{R}_{\mathrm{f} n} \mathrm{CH}_{2} \mathrm{OH}(n=11,13,15)$ were first converted to the triflates $\mathrm{R}_{\mathrm{f} n} \mathrm{CH}_{2} \mathrm{OTf}$ using pyridine and triflic anhydride $\left(\mathrm{Tf}_{2} \mathrm{O}\right)$ in (trifluoromethyl)benzene $\left(\mathrm{CF}_{3} \mathrm{C}_{6} \mathrm{H}_{5}\right)$, an amphoteric solvent that is usually able to dissolve appreciable quantities of both fluorous and non-fluorous solutes [33]. The reactions with $n=11$ and 13 were conducted at $0{ }^{\circ} \mathrm{C}$, and work-ups gave the expected triflates in $60-61 \%$ yields. In contrast, only traces of product were obtained with $n=15$, presumably due to the poor solubility of the alcohol in virtually any medium. However, the solubilities of fluorous compounds are often highly temperature dependent $[28,34]$, and an analogous reaction at room temperature gave $\mathrm{R}_{\mathrm{f} 15} \mathrm{CH}_{2} \mathrm{OTf}$ in $22 \%$ yield. The triflates were white solids with some solubility in acetone. They were characterized by IR and NMR $\left({ }^{1} \mathrm{H},{ }^{13} \mathrm{C}\left\{{ }^{1} \mathrm{H}\right\},{ }^{19} \mathrm{~F}\left\{{ }^{1} \mathrm{H}\right\}\right)$ spectroscopy and microanalyses as summarized in the experimental section.

The triflates were treated with $\mathrm{NaI}$ in acetone at $75^{\circ} \mathrm{C}$. Over the course of $24 \mathrm{~h}$, high conversions to the corresponding fluorous iodides $\mathrm{R}_{\mathrm{f} n} \mathrm{CH}_{2} \mathrm{I}$ were realized, although at rates much slower than with non-fluorous analogs. Work-ups afforded the products as analytically pure white solids in $58-69 \%$ yields, which were characterized analogously to the triflates. All were to some degree soluble in acetone, but as the perfluoroalkyl group lengthened, appropriate cosolvents were required to achieve significant concentrations. In order to obtain ${ }^{13} \mathrm{C}$ NMR spectra ( $n=13,15), \mathrm{C}_{6} \mathrm{~F}_{6}$ - which is technically a non-fluorous solvent [35] but is nonetheless often effective with fluorous solutes was employed.

Importantly, these fluorous aliphatic iodides were more fluorophilic than those mentioned in the introduction. Representative partition coefficients were determined as described in the experimental section. Those for $\mathrm{R}_{\mathrm{f} 15} \mathrm{CH}_{2} \mathrm{I}$ ranged from $>99:<1$ for $\mathrm{CF}_{3} \mathrm{C}_{6} \mathrm{~F}_{11}$ /toluene to $87: 13$ for $\mathrm{CF}_{3} \mathrm{C}_{6} \mathrm{~F}_{11}$ /acetone. The $\mathrm{CF}_{3} \mathrm{C}_{6} \mathrm{~F}_{11}$ /toluene partition coefficient of $\mathrm{R}_{\mathrm{f} 11} \mathrm{CH}_{2} \mathrm{I}$ was also $>99:<1$.

Next, $\mathrm{CH}_{3} \mathrm{CN} / \mathrm{C}_{6} \mathrm{~F}_{6}$ solutions of the fluorous aliphatic iodides $(n=11,13)$ were treated with aqueous $\mathrm{NaOCl}$ and conc. $\mathrm{HCl}$. The combination of $\mathrm{HCl}$ and a mild oxidant generates $\mathrm{Cl}_{2}$, providing a "greener" synthetic approach to iodine(III) dichlorides [36-38]. Accordingly, the target molecules $\mathrm{R}_{\mathrm{f} n} \mathrm{CH}_{2} \mathrm{ICl}_{2}$ precipitated in $33-81 \%$ yields. However, the poor solubilities of these pale yellow powders precluded further purification by the usual protocols. Microanalyses confirmed the presence of chlorine.

\begin{tabular}{|c|c|c|c|c|c|c|}
\hline \multirow{2}{*}{$\mathrm{R}_{\mathrm{fn}} \mathrm{CH}_{2} \mathrm{OH}$} & $\begin{array}{l}\text { 1. pyridine } \\
\text { 2. } \mathrm{Tf}_{2} \mathrm{O} \\
\end{array}$ & $\mathrm{R}_{\mathrm{fn}} \mathrm{CH}_{2} \mathrm{OTf}$ & $\mathrm{Nal}$ & & $\mathrm{NaOCl} / \mathrm{HCl}$ & $R_{0}$ \\
\hline & $\begin{array}{l}\mathrm{CF}_{3} \mathrm{C}_{6} \mathrm{H}_{5} \\
0-222^{\circ} \mathrm{C}\end{array}$ & $\begin{array}{r}n=11,61 \% \\
13,60 \% \\
15,22 \%\end{array}$ & $\begin{array}{c}\text { acetone } \\
75^{\circ} \mathrm{C}\end{array}$ & $\begin{array}{r}n=11,69 \% \\
13,58 \% \\
15,60 \%\end{array}$ & $\begin{array}{l}\mathrm{CH}_{3} \mathrm{CN} / \\
\mathrm{C}_{6} \mathrm{~F}_{6}, \mathrm{rt}\end{array}$ & 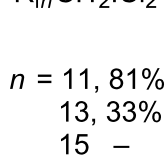 \\
\hline
\end{tabular}


When ${ }^{1} \mathrm{H}$ NMR spectra were recorded in acetone- $d_{6}$, new $\mathrm{CH}_{2}$ signals $1.37-1.38 \mathrm{ppm}$ downfield of those of the precursors $\mathrm{R}_{\mathrm{f} n} \mathrm{CH}_{2} \mathrm{I}$ were apparent. However, the NMR samples slowly became greenish yellow, suggestive of dissolved $\mathrm{Cl}_{2}$, and the starting iodides were usually evident. The use of $\mathrm{Cl}_{2}$ in place of $\mathrm{NaOCl} / \mathrm{HCl}$ did not give better results.

Syntheses and reactions, $\mathrm{R}_{\mathrm{fO}} \mathrm{CH}_{2} \mathrm{I}(\boldsymbol{x}=\mathbf{2 - 5})$. There is an ongoing effort in fluorous chemistry to decrease reliance on perfluorooctyl containing building blocks, which are associated with a variety of environmental issues [39]. One approach is to switch to related ethereal phase tags or "ponytails" [40,41]. Accordingly, oligomeric fluorous ethers that terminate in $\mathrm{CH}_{2} \mathrm{OH}$ groups, $\mathrm{CF}_{3} \mathrm{CF}_{2} \mathrm{CF}_{2} \mathrm{O}\left(\mathrm{CF}\left(\mathrm{CF}_{3}\right) \mathrm{CF}_{2} \mathrm{O}\right)_{x} \mathrm{CF}\left(\mathrm{CF}_{3}\right) \mathrm{CH}_{2} \mathrm{OH}$, are commercially available. These are abbreviated $\mathrm{R}_{\mathrm{fO} x} \mathrm{CH}_{2} \mathrm{OH}$, and the ethereal oxygen atoms have essentially no Lewis base character. In some cases, $\mathrm{CF}_{2} \mathrm{CF}_{2} \mathrm{OCF}\left(\mathrm{CF}_{3}\right) \mathrm{CF}_{2} \mathrm{OCF}\left(\mathrm{CF}_{3}\right)$ segments have been found to impart higher fluorophilicites than similar perfluoroalkyl groups [42]. However, the multiple $\mathrm{CF}\left(\mathrm{CF}_{3}\right)$ stereocenters are disadvantageous, as they render such compounds mixtures of diastereomers, presenting an impediment to crystallization. In some cases, NMR spectra do not differentiate the diastereomers, and in other cases more complex signal patterns are evident.

As shown in Scheme 3, the oligomeric alcohols $(x=2-5)$ were elaborated as described for the non-ethereal alcohols $\mathrm{R}_{\mathrm{f} n} \mathrm{CH}_{2} \mathrm{OH}$ and a previous report involving the lower nonoligomeric homolog $\mathrm{R}_{\mathrm{fO} 1} \mathrm{CH}_{2} \mathrm{OH}$ ( $x=1$ [5]). They were first converted to the triflates $\mathrm{R}_{\mathrm{fO} x} \mathrm{CH}_{2} \mathrm{OTf}$ using pyridine and triflic anhydride $\left(\mathrm{Tf}_{2} \mathrm{O}\right)$. These were soluble in hexane/ethyl acetate and isolated as analytically pure colorless oils in $84-93 \%$ yields. Subsequent reactions with $\mathrm{NaI}$ in acetone $\left(70-75^{\circ} \mathrm{C}\right.$, $x=2,4,5$ ) gave the corresponding iodides $\mathrm{R}_{\mathrm{fO} x} \mathrm{CH}_{2} \mathrm{I}$ as colorless liquids in $81-91 \%$ yields. Unfortunately, efforts to oxidize these compounds to the corresponding iodine(III) dichlorides using the conditions in Scheme 1 and Scheme 2 were unsuccessful. NMR analyses of crude reaction mixtures showed only starting material.

Attempted syntheses of $\mathbf{R}_{\mathbf{f} \boldsymbol{n}} \mathbf{I C l}$. Prior to the efforts described in the previous sections, iodine(III) dichlorides derived from perfluoroalkyl iodides $\mathrm{R}_{\mathrm{f} n} \mathrm{I}$ were considered as targets. Since these lack $\mathrm{sp}^{3}$ carbon-hydrogen bonds, they are not susceptible to possible chlorination or other degradation under free radical chlorination conditions. However, no reactions were observed when $\mathrm{R}_{\mathrm{f} n} \mathrm{I}$ were treated with $\mathrm{Cl}_{2}$ or $\mathrm{NaOCl} / \mathrm{HCl}$.

Nonetheless, perfluoroalkyl iodides $\mathrm{R}_{\mathrm{f} n} \mathrm{I}(n=6-8,10,12)$ can be oxidized using various recipes (e.g., $80 \% \mathrm{H}_{2} \mathrm{O}_{2}$ in trifluoroacetic acid anhydride) to the iodine(III) bis(trifluoroacetates) $\mathrm{R}_{\mathrm{f} n} \mathrm{I}\left(\mathrm{OCOCF}_{3}\right)_{2}$ in high isolated yields $[18,19,21]$. It was thought that these might, in turn, react with $\mathrm{TMSCl}$ as sketched in Scheme 4 to provide "back door" entries to the target compounds $\mathrm{R}_{\mathrm{f} n} \mathrm{ICl}_{2}$. Indeed, when these reactions were carried out, the samples exhibited the appropriate characteristic bright yellow colors $(n=6,8)$. However, upon work-up only the original perfluoroalkyl iodides $\mathrm{R}_{\mathrm{f} n} \mathrm{I}$ were isolated. Hence, it is concluded that the target compounds are thermodynamically and kinetically unstable with respect to $\mathrm{Cl}_{2}$ elimination, consistent with the failure of the direct reaction and a lower Lewis basicity of the iodine atom as compared to $\mathrm{R}_{\mathrm{f} n} \mathrm{CH}_{2} \mathrm{I}$.

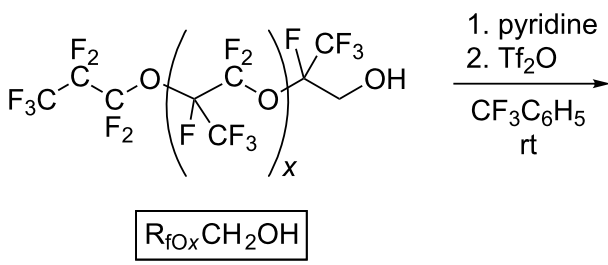

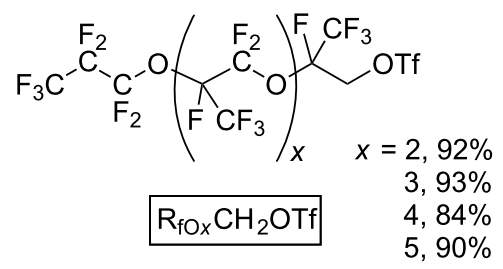
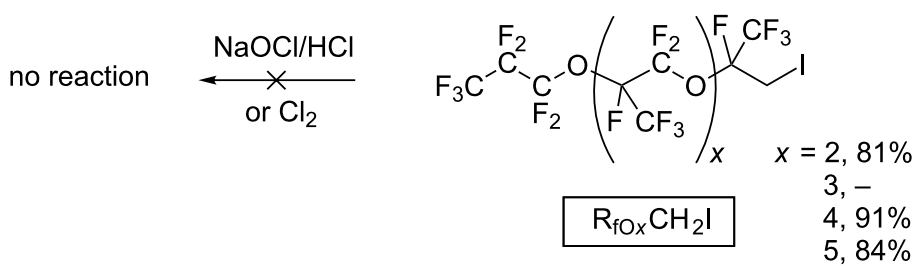


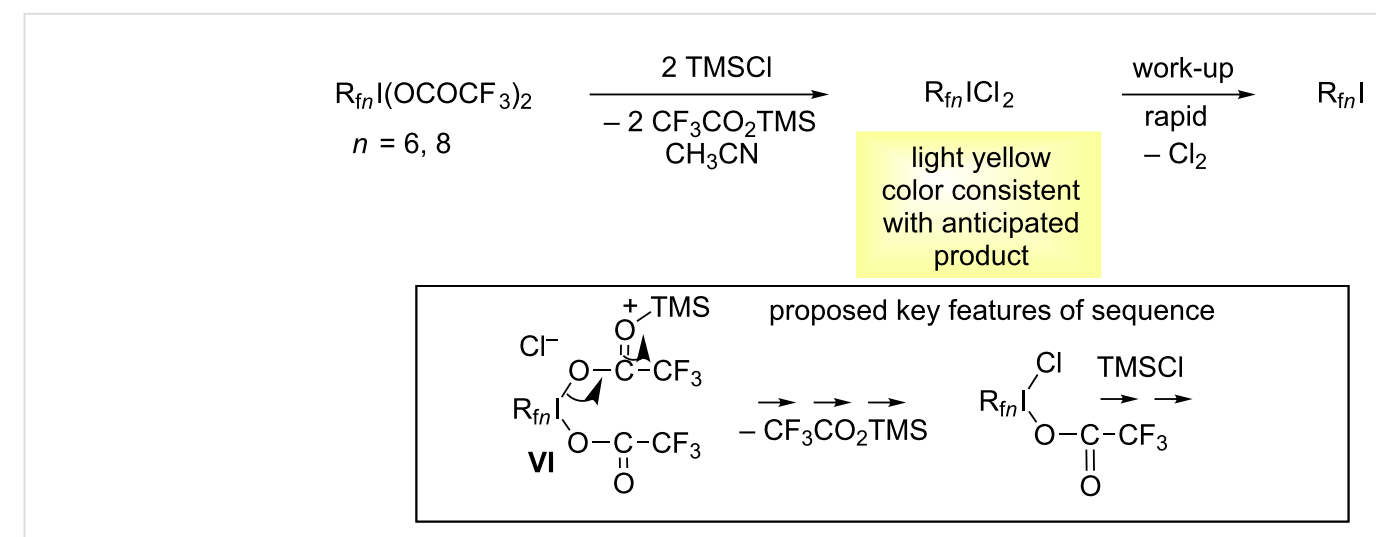

Scheme 4: Attempted syntheses of aliphatic fluorous iodine(III) dichlorides $\mathrm{R}_{\mathrm{fn}} \mathrm{ICl}$.

After these experiments were carried out, we became aware of the isolation of $\mathrm{CF}_{3} \mathrm{ICl}_{2}\left(\mathrm{R}_{\mathrm{f} 1} \mathrm{ICl}_{2}\right)$ from the reaction of $\mathrm{CF}_{3} \mathrm{IClF}$ and $\mathrm{TMSCl}$ at $-40{ }^{\circ} \mathrm{C}[43]$. This route is conceptually similar to that shown in Scheme 4, and a crystal structure of $\mathrm{CF}_{3} \mathrm{ICl}_{2}$ could even be obtained. However, consistent with our observations, the compound decomposed above $-35^{\circ} \mathrm{C}$.

Syntheses and reactions, aryl iodides with one perfluoroalkyl group. Aromatic compounds are challenging to render highly fluorophilic $[16,30,44]$. For example, the singly-phasetagged arene $\mathrm{C}_{6} \mathrm{H}_{5} \mathrm{CH}_{2} \mathrm{CH}_{2} \mathrm{CH}_{2} \mathrm{R}_{\mathrm{f} 8}$ gives a 49.5:50.5 $\mathrm{CF}_{3} \mathrm{C}_{6} \mathrm{~F}_{11}$ /toluene partition coefficient. Values for doubly tagged analogs fall into the range (90.7-91.2):(9.3-8.8) $(o, m, p$-isomers), and that for the triply tagged species $1,3,5-$ $\mathrm{C}_{6} \mathrm{H}_{3}\left(\mathrm{CH}_{2} \mathrm{CH}_{2} \mathrm{CH}_{2} \mathrm{R}_{\mathrm{f} 8}\right)_{3}$ is $>99.7:<0.3$ [30]. As noted above, longer perfluoroalkyl segments increase fluorophilicities, as do shorter methylene segments (compare the partition coefficients of $\mathrm{C}_{6} \mathrm{H}_{5} \mathrm{R}_{\mathrm{f} 8}$ (77.5:22.5) or 1,4-( $\left(\mathrm{R}_{\mathrm{f} 8}\right)_{2} \mathrm{C}_{6} \mathrm{H}_{4}$ (99.3:0.7) with the preceding examples [29]). Thus, in considering various fluorous aryliodine(III) dichloride targets, initial efforts were directed at systems with at least two $\mathrm{R}_{\mathrm{f} n}$ substituents per arene ring. Given the ready isolation of the dinitro-substituted aryliodine(III) dichloride II-Me in Scheme 1 [31], this was seen as a surefire objective.

However, this was not to be, so the results in this and the following section are presented in inverse chronological order, focusing first on arenes with one $\mathrm{R}_{\mathrm{f} n}$ substituent. As shown in Scheme 5 (top), the commercially available meta diiodide 1,3$\mathrm{C}_{6} \mathrm{H}_{4} \mathrm{I}_{2}$ was treated with copper (1.0 equiv) and $\mathrm{R}_{\mathrm{f} 6} \mathrm{I}(0.5$ equiv; a deficiency to help suppress dialkylation) in DMSO at $110^{\circ} \mathrm{C}$. Similar recipes have previously been used to couple aryl iodides and $\mathrm{R}_{\mathrm{f} n} \mathrm{I}$ building blocks $[45,46]$. Work-up gave the target compound $1,3-\mathrm{R}_{\mathrm{f} 6} \mathrm{C}_{6} \mathrm{H}_{4} \mathrm{I}$ in $60 \%$ yield (based upon limiting $\mathrm{R}_{\mathrm{f} 6} \mathrm{I}$ ).

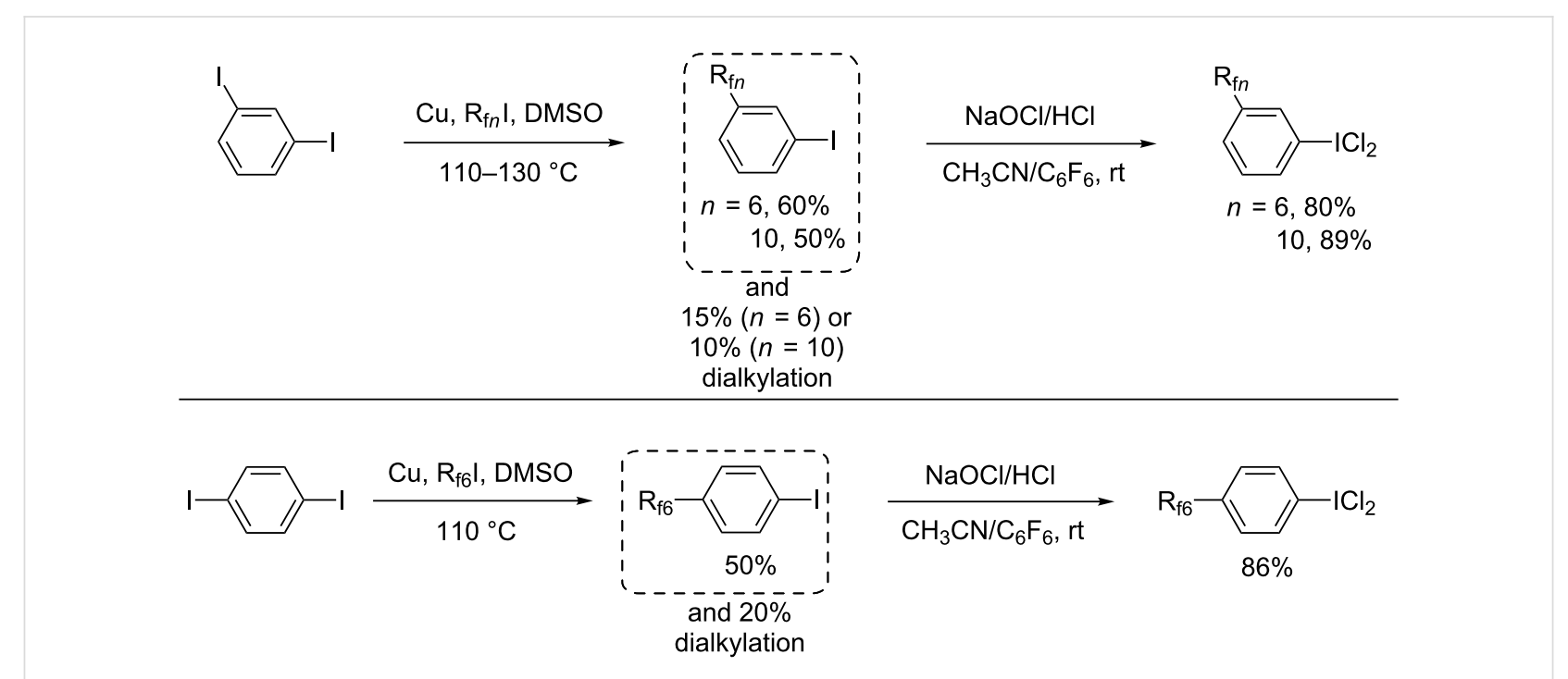


Some of the previously reported dialkylation product 1,3$\left(\mathrm{R}_{\mathrm{f} 6}\right)_{2} \mathrm{C}_{6} \mathrm{H}_{4}$ was also formed $[47,48]$, but was easily separated due to its differential fluorophilicity (extraction of a $\mathrm{CH}_{3} \mathrm{CN}$ solution with perfluorohexane). An analogous procedure with $\mathrm{R}_{\mathrm{f} 10} \mathrm{I}$ gave the higher homolog $1,3-\mathrm{R}_{\mathrm{f} 10} \mathrm{C}_{6} \mathrm{H}_{4} \mathrm{I}$ in $50 \%$ yield [9], and a lesser amount of what was presumed to be the dialkylation product. The analogous para diiodide $1,4-\mathrm{C}_{6} \mathrm{H}_{4} \mathrm{I}_{2}$ gave parallel chemistry, as illustrated by the reaction with $\mathrm{R}_{\mathrm{f} 6} \mathrm{I}$ to give $1,4-\mathrm{R}_{\mathrm{f} 6} \mathrm{C}_{6} \mathrm{H}_{4} \mathrm{I}(50 \%[4,12])$ in Scheme 5 (bottom).

The three aryl iodides $\mathrm{R}_{\mathrm{f} n} \mathrm{C}_{6} \mathrm{H}_{4} \mathrm{I}$ thus obtained were treated with $\mathrm{NaOCl} / \mathrm{HCl}$ per the sequence in Scheme 2. As shown in Scheme 5, work-ups gave the corresponding iodine(III) dichlorides $\mathrm{R}_{\mathrm{f} n} \mathrm{C}_{6} \mathrm{H}_{4} \mathrm{ICl}_{2}$ as pale yellow powders in $80-89 \%$ yields. Although these were clean by NMR, only one gave a correct microanalysis. As illustrated in Figure $\mathrm{S} 1$ (Supporting Information File 1), $\mathrm{CDCl}_{3} / \mathrm{C}_{6} \mathrm{~F}_{6}$ solutions of $1,3-\mathrm{R}_{\mathrm{f} 6} \mathrm{C}_{6} \mathrm{H}_{4} \mathrm{ICl}_{2}$ and 1,4$\mathrm{R}_{\mathrm{f} 6} \mathrm{C}_{6} \mathrm{H}_{4} \mathrm{ICl}_{2}$ containing an internal standard were monitored by ${ }^{1} \mathrm{H}$ NMR. Slow partial evolution of $\mathrm{Cl}_{2}$ to give the iodides 1,3$\mathrm{R}_{\mathrm{f} 6} \mathrm{C}_{6} \mathrm{H}_{4} \mathrm{I}$ and $1,4-\mathrm{R}_{\mathrm{f} 6} \mathrm{C}_{6} \mathrm{H}_{4} \mathrm{I}$ was observed $(7 \%$ and $27 \%$ conversion over $60 \mathrm{~h}$, respectively).

Syntheses and reactions, aryl iodides with two perfluoroalkyl groups. In a previously reported procedure [48], the diiodide 1,3- $\mathrm{C}_{6} \mathrm{H}_{4} \mathrm{I}_{2}$ was treated with copper (5.1 equiv) and $\mathrm{R}_{\mathrm{f} 6} \mathrm{I}$ (2.2 equiv) in DMSO at $140{ }^{\circ} \mathrm{C}$. As shown in Scheme 6 (top), the bis(perfluorohexyl) adduct $1,3-\left(\mathrm{R}_{\mathrm{f} 6}\right)_{2} \mathrm{C}_{6} \mathrm{H}_{4}$, which was the undesired byproduct in Scheme 5 (top), was isolated in $75 \%$ yield. Subsequent iodination using NIS in fuming $\mathrm{H}_{2} \mathrm{SO}_{4} /$ $\mathrm{CF}_{3} \mathrm{CO}_{2} \mathrm{H}$ afforded the "all meta" iodide 1,3,5-( $\left(\mathrm{R}_{\mathrm{f} 6}\right)_{2} \mathrm{C}_{6} \mathrm{H}_{3} \mathrm{I}$ in $77 \%$ yield. The substitution pattern was evident from the ${ }^{1} \mathrm{H}$ NMR spectrum.

When $\mathrm{Cl}_{2}$ gas was sparged through a $\mathrm{CF}_{3} \mathrm{C}_{6} \mathrm{H}_{5}$ solution of $1,3,5-\left(\mathrm{R}_{\mathrm{f} 6}\right)_{2} \mathrm{C}_{6} \mathrm{H}_{3} \mathrm{I}$ at $-30{ }^{\circ} \mathrm{C}$ to $-35^{\circ} \mathrm{C}$, the sample turned bright yellow. Two aliquots were removed. The ${ }^{1} \mathrm{H}$ NMR spectrum of one (Figure 1b) showed two downfield shifted signals (cf. Figure 1a), which were attributed to the target molecule 1,3,5- $\left(\mathrm{R}_{\mathrm{f} 6}\right)_{2} \mathrm{C}_{6} \mathrm{H}_{3} \mathrm{ICl}_{2}$. Integration indicated 77:23 and 75:25 $\mathrm{ArICl}_{2} / \mathrm{ArI}$ ratios prior to and after solvent removal (room temperature, rotary evaporation). The isolated material was redissolved in $\mathrm{CF}_{3} \mathrm{C}_{6} \mathrm{H}_{5}$ and kept at $-35{ }^{\circ} \mathrm{C}$. After $7 \mathrm{~d}$, the solvent was again removed by rotary evaporation, giving a $65: 35$ $\mathrm{ArICl}_{2} / \mathrm{ArI}$ mixture (Figure 1d). The solvent was removed from the second aliquot by oil pump vacuum at $-40{ }^{\circ} \mathrm{C}$. This gave a 35:65 $\mathrm{ArICl}_{2} / \mathrm{ArI}$ mixture as a pale white solid (Figure 1c). A variety of attempts to achieve higher conversions or isolate pure $1,3,5-\left(\mathrm{R}_{\mathrm{f} 6}\right)_{2} \mathrm{C}_{6} \mathrm{H}_{3} \mathrm{ICl}_{2}$ were unsuccessful. It was concluded that $1,3,5-\left(\mathrm{R}_{\mathrm{f} 6}\right)_{2} \mathrm{C}_{6} \mathrm{H}_{3} \mathrm{ICl}_{2}$ was much more labile with respect to $\mathrm{Cl}_{2}$ evolution than the fluorous aryliodine(III) dichlorides shown in Scheme 5, and that the $75-80 \%$ conversions reflected a thermodynamic limit.

Next, analogs of 1,3,5-( $\left(\mathrm{R}_{\mathrm{f} 6}\right)_{2} \mathrm{C}_{6} \mathrm{H}_{3} \mathrm{ICl}_{2}$ with less electron-deficient iodine atoms were sought. As shown in Scheme 1, related fluorous aryliodine(III) dichlorides with three-methylene spacers, $\left(\mathrm{R}_{\mathrm{f} 8} \mathrm{CH}_{2} \mathrm{CH}_{2} \mathrm{CH}_{2}\right)_{2} \mathrm{C}_{6} \mathrm{H}_{3} \mathrm{ICl}_{2}$, had been isolated (the isomers III, IV) [17]. Recently, a potential precursor with twomethylene spacers, $1,3-\left(\mathrm{R}_{\mathrm{f} 8} \mathrm{CH}_{2} \mathrm{CH}_{2}\right)_{2} \mathrm{C}_{6} \mathrm{H}_{4}$, became readily available [49]. Accordingly, it could be iodinated with $\mathrm{I}_{2} / \mathrm{H}_{5} \mathrm{IO}_{6}$ as shown in Scheme 6 (bottom) to give 1,2,4$\left(\mathrm{R}_{\mathrm{f} 8} \mathrm{CH}_{2} \mathrm{CH}_{2}\right)_{2} \mathrm{C}_{6} \mathrm{H}_{3} \mathrm{I}$ [50] in $93 \%$ yield after work-up. The ${ }^{1} \mathrm{H}$ NMR spectrum clearly indicated the regioisomer in which the iodide is ortho and para to the two alkyl substituents. This contrasts with the iodination of $1,3-\left(\mathrm{R}_{\mathrm{f} 6}\right)_{2} \mathrm{C}_{6} \mathrm{H}_{4}$, in which the substituents function as meta directing groups.

As shown in Scheme 6, reactions of $\mathrm{C}_{6} \mathrm{~F}_{6}$ or perfluoroheptane solutions of $1,2,4-\left(\mathrm{R}_{\mathrm{f} 8} \mathrm{CH}_{2} \mathrm{CH}_{2}\right)_{2} \mathrm{C}_{6} \mathrm{H}_{3} \mathrm{I}$ and $\mathrm{NaOCl} / \mathrm{HCl}$ gave the corresponding iodine(III) dichloride 1,2,4-
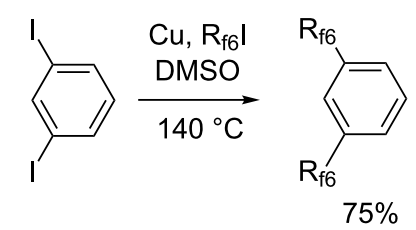

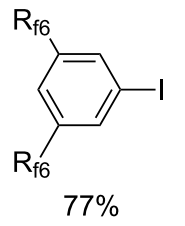

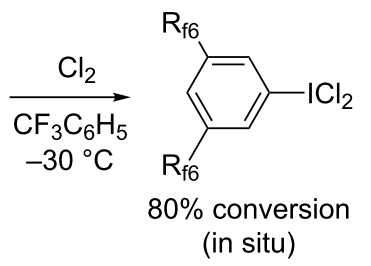
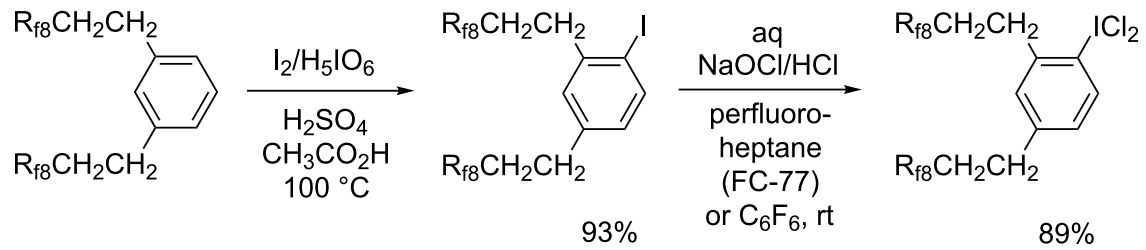

Scheme 6: Syntheses of aromatic fluorous compounds with two perfluoroalkyl groups. 


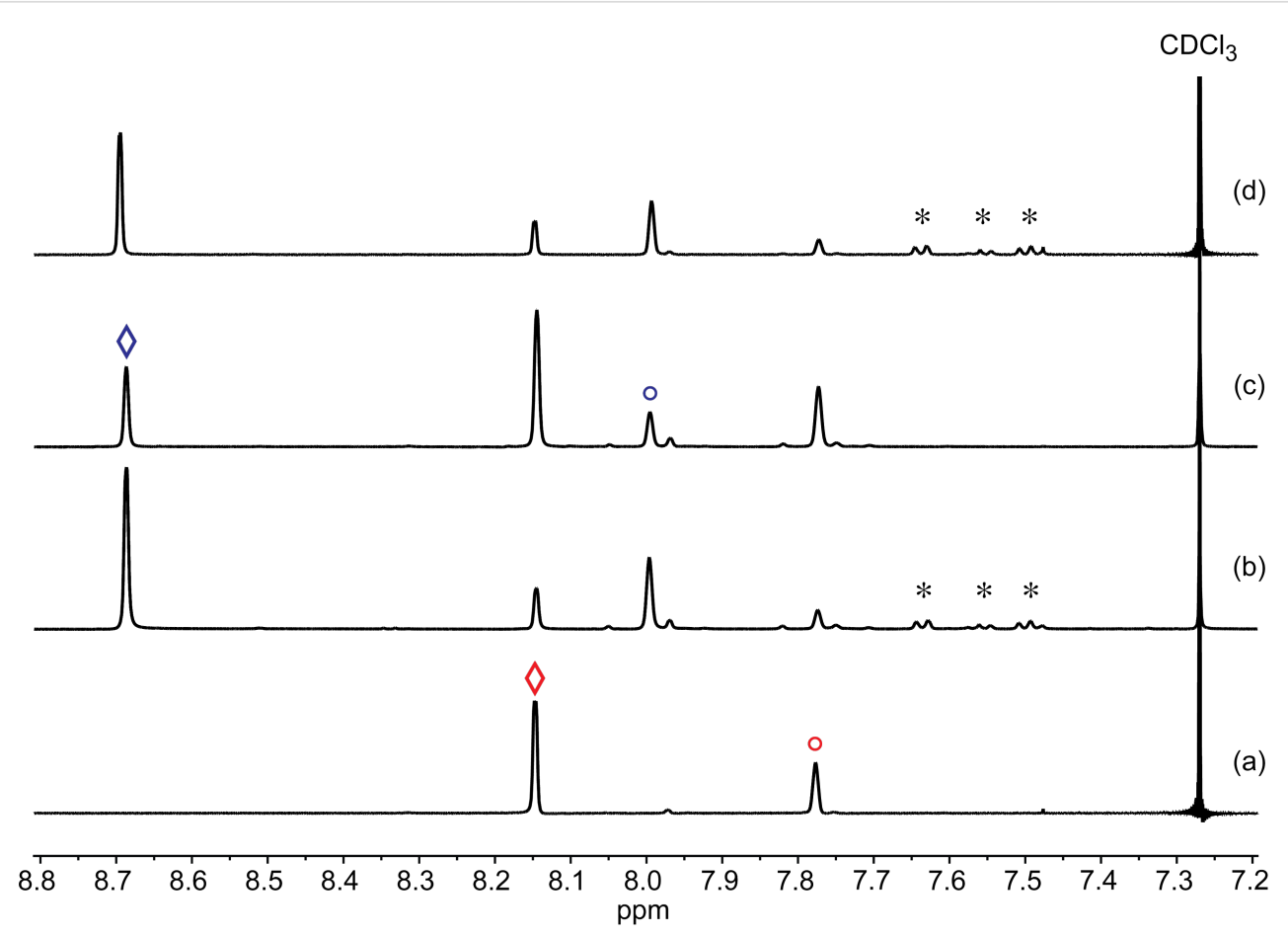

Figure 1: Partial ${ }^{1} \mathrm{H}$ NMR spectra ( $\mathrm{sp}^{2} \mathrm{CH}, 500 \mathrm{MHz}, \mathrm{CDCl}_{3}$ ) relating to the reaction of 1,3,5-( $\left(\mathrm{R}_{\mathrm{f}}\right)_{2} \mathrm{C}_{6} \mathrm{H}_{3} \mathrm{l}$ and $\mathrm{Cl}_{2}$ in $\mathrm{CF}_{3} \mathrm{C}_{6} \mathrm{H}_{5}$ at -30 to $-35^{\circ} \mathrm{C}$ : (a) starting 1,3,5-( $\left(\mathrm{R}_{\mathrm{f}}\right)_{2} \mathrm{C}_{6} \mathrm{H}_{3} \mathrm{l} ;$ (b) aliquot taken after $24 \mathrm{~h}$ and removing nearly all $\mathrm{CF}_{3} \mathrm{C}_{6} \mathrm{H}_{5}$ ( ${ }^{*}=$ residual signals) by rotary evaporation $\left(75: 25 \mathrm{ArICl}_{2} /\right.$ Arl); (c) aliquot taken after $24 \mathrm{~h}$ and removing all solvents by oil pump vacuum at $-40{ }^{\circ} \mathrm{C}\left(35: 65 \mathrm{ArlCl}_{2} / \mathrm{Arl}\right)$; (d) the sample from b, which was redissolved in $\mathrm{CF}_{3} \mathrm{C}_{6} \mathrm{H}_{5}$, kept at $-35^{\circ} \mathrm{C}$ for $7 \mathrm{~d}$, and worked up as in b $\left(65: 35 \mathrm{ArlCl}_{2} / \mathrm{Arl}\right)$. The signals for the protons para and ortho to the iodine atoms are denoted ${ }^{\circ}$ and $\diamond\left(\right.$ red $=$ Arl; blue $\left.=\mathrm{ArICl}_{2}\right)$.

$\left(\mathrm{R}_{\mathrm{f} 8} \mathrm{CH}_{2} \mathrm{CH}_{2}\right)_{2} \mathrm{C}_{6} \mathrm{H}_{3} \mathrm{ICl}_{2}$ [50] as a white powder in $89 \%$ yield. This material was stable at room temperature and gave a microanalysis consistent with a monohydrate. Hence, the iodine atom in benzenoid compounds with two $\mathrm{R}_{\mathrm{f} 8} \mathrm{CH}_{2} \mathrm{CH}_{2}$ substituents is sufficiently Lewis basic to support a dichloride, but analogs with two $\mathrm{R}_{\mathrm{f} 6}$ substituents are not.

Structural and computational data. Crystal structures of fluorous compounds were virtually unknown 20 years ago [51], so opportunities to acquire structural data are usually seized. Crystals of 1,3,5-( $\left(\mathrm{R}_{\mathrm{f} 6}\right)_{2} \mathrm{C}_{6} \mathrm{H}_{3} \mathrm{I}$ could be grown as described in the experimental section. X-ray data were collected, and the structure determined, as summarized in Table 1 and the experimental section. Two views of the molecular structure and key metrical parameters are provided in Figure 2. Two perspectives of the unit cell $(Z=8)$ are provided in Figure 3. There are some unusual features associated with the packing and space group, and these are treated in the discussion section.

In order to help interpret the accessibilities and/or stabilities of the various iodine(III) dichlorides described above, the gas phase free energies of chlorination

$$
\mathrm{RI}(\mathrm{g}) \text { or } \mathrm{Arl}(\mathrm{g})+\mathrm{Cl}_{2}(\mathrm{~g}) \longrightarrow \mathrm{RICl}_{2}(\mathrm{~g}) \text { or } \mathrm{ArICl}_{2}(\mathrm{~g})
$$

were computed by DFT methods as described in the experimental section and summarized in Table S1 (Supporting Information File 1). The data are presented in "ladder format" in Figure 4, with the substrates that undergo more exergonic chlorinations placed higher. The energy difference between any pair of compounds is equal to that expressed by the corresponding isodesmic equation:

$$
\begin{array}{r}
\mathrm{RI}(\mathrm{g}) \text { or } \operatorname{Arl}(\mathrm{g})+\mathrm{R}^{\prime} \mathrm{ICl}_{2}(\mathrm{~g}) \text { or } \operatorname{Ar}^{\prime} \mathrm{ICl}_{2}(\mathrm{~g}) \longrightarrow \\
\mathrm{RICl}_{2}(\mathrm{~g}) \text { or } \mathrm{ArICl}_{2}(\mathrm{~g})+\mathrm{R}^{\prime} \mathrm{I}(\mathrm{g}) \text { or } \operatorname{Ar}^{\prime} \mathrm{I}(\mathrm{g})
\end{array}
$$

The validity of the data was supported by the good agreement of the computed structure of $1,3,5-\left(\mathrm{R}_{\mathrm{f} 6}\right)_{2} \mathrm{C}_{6} \mathrm{H}_{3} \mathrm{I}$ with the crystal structure (Figure 2). An overlay, provided in Figure S2 (Supporting Information File 1), shows only very slightly increasing conformational differences as the perfluorohexyl groups extend from the arene. For the aliphatic compounds $\left(\mathrm{R}_{\mathrm{f} n} \mathrm{I}, \mathrm{R}_{\mathrm{f} n} \mathrm{CH}_{2} \mathrm{I}\right.$, $\mathrm{R}_{\mathrm{fO} x} \mathrm{CH}_{2} \mathrm{ICl}_{2}$ ), the free energies of chlorination were calculated for a series of chain lengths. As summarized in Figure 4 and tabulated in Table S1 (Supporting Information File 1), the $\Delta G$ values within each series varied by less than $0.5 \mathrm{kcal} / \mathrm{mol}$. In all cases, vertical ionization potentials (not presented) followed analogous trends. 


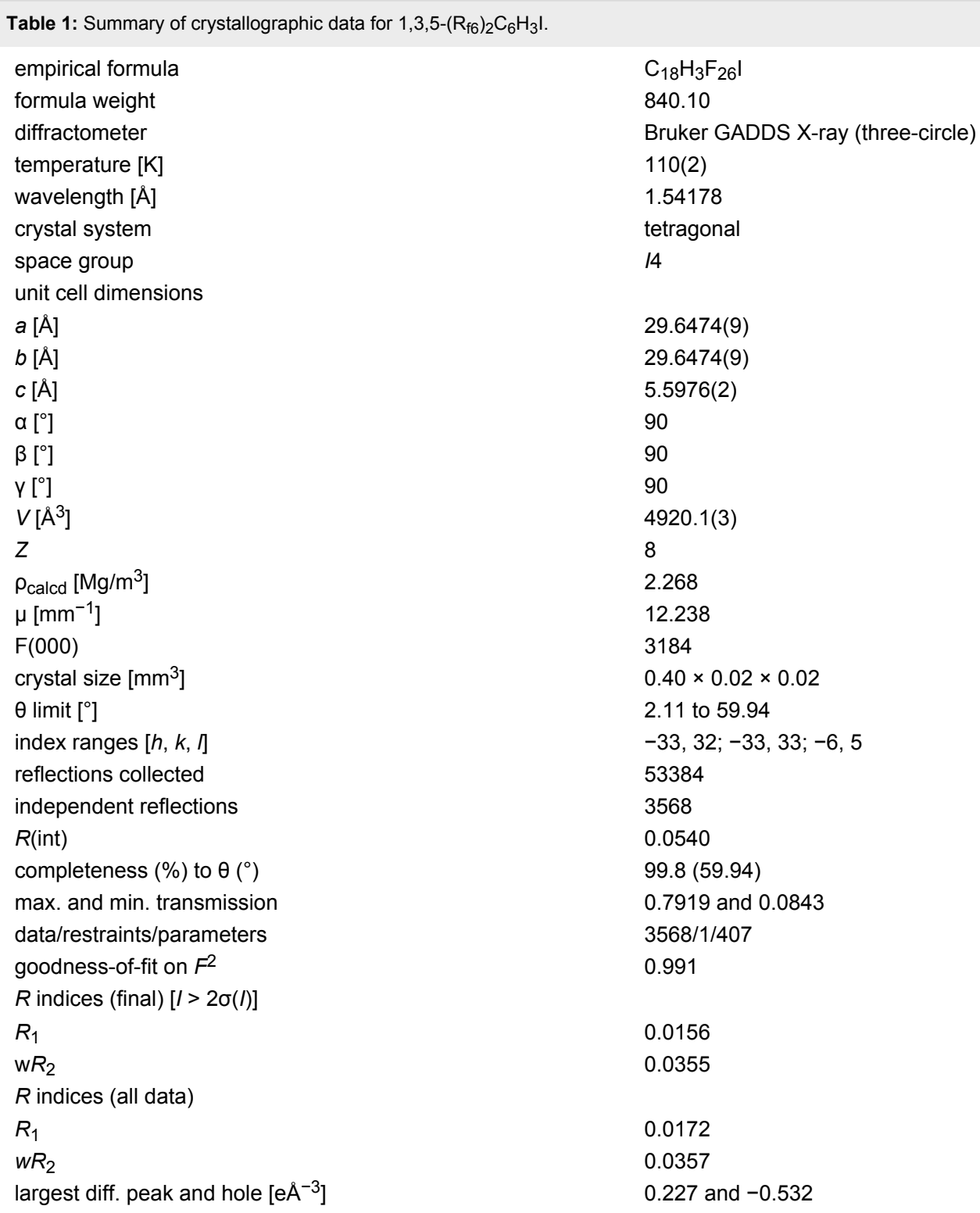

The iodine(III) dichlorides formed in the more exergonic reactions (upper portion of Figure 4) would be expected to be more stable with respect to $\mathrm{Cl}_{2}$ evolution. Thus, the data are consistent with the stability order $\mathrm{R}_{\mathrm{f} n} \mathrm{CH}_{2} \mathrm{ICl}_{2} \gg \mathrm{R}_{\mathrm{f} n} \mathrm{ICl}_{2}$ evident from Scheme 2 and Scheme 4. However, they also imply that the ethereal systems $\mathrm{R}_{\mathrm{fO} x} \mathrm{CH}_{2} \mathrm{ICl}_{2}$ (Scheme $3 ;-0.65 \mathrm{kcal} / \mathrm{mol}$, $x=1)$ should be more stable than $\mathrm{R}_{\mathrm{f} n} \mathrm{CH}_{2} \mathrm{ICl}_{2}(-0.53$ to $-0.59 \mathrm{kcal} / \mathrm{mol}, n=4-8)$. All attempts to generate the former have been unsuccessful to date. Hence, there is either a kinetic barrier to the formation of $\mathrm{R}_{\mathrm{fO} x} \mathrm{CH}_{2} \mathrm{ICl}_{2}$ that is not overcome under the conditions of Scheme 3, or an unrecognized, presumably non-electronic, destabilizing feature.

In the same vein, there must be a mitigating factor, such as solubility, that allows the isolation of the dinitro-substituted aryl-

iodine(III) dichloride II-Me in pure form (Scheme 1), but not the bis(perfluorohexyl) species 1,3,5-( $\left.\mathrm{R}_{\mathrm{f} 6}\right)_{2} \mathrm{C}_{6} \mathrm{H}_{3} \mathrm{ICl}_{2}$ (Scheme 6, Figure 1). The latter is derived from a more Lewis basic aryl iodide, with $\mathrm{Cl}_{2}$ addition $0.83 \mathrm{kcal} / \mathrm{mol}$ more favorable. The ortho methyl group in II-Me plays a moderately stabilizing role, with $\mathrm{Cl}_{2}$ addition to $\mathrm{I}-\mathrm{Me} 0.73 \mathrm{kcal} / \mathrm{mol}$ more favorable than $\mathbf{I}$. Otherwise, the computations (carried out with $\mathrm{R}_{\mathrm{f} 6}$ groups to aid comparability) nicely predict the relative stabilities of the fluorous aryliodine(III) dichlorides $(1,2,4$ $\left(\mathrm{R}_{\mathrm{f} 8} \mathrm{CH}_{2} \mathrm{CH}_{2}\right)_{2} \mathrm{C}_{6} \mathrm{H}_{3} \mathrm{ICl}_{2}$ [50] > 1,4- $\mathrm{R}_{\mathrm{f} 6} \mathrm{C}_{6} \mathrm{H}_{4} \mathrm{ICl}_{2}>1,3-$ $\left.\mathrm{R}_{\mathrm{f} 6} \mathrm{C}_{6} \mathrm{H}_{4} \mathrm{ICl}_{2}>1,3,5-\left(\mathrm{R}_{\mathrm{f} 6}\right)_{2} \mathrm{C}_{6} \mathrm{H}_{3} \mathrm{ICl}_{2}\right)$.

\section{Discussion}

The preceding experimental data define the stability limits associated with a broad range of fluorous aliphatic and aromatic 


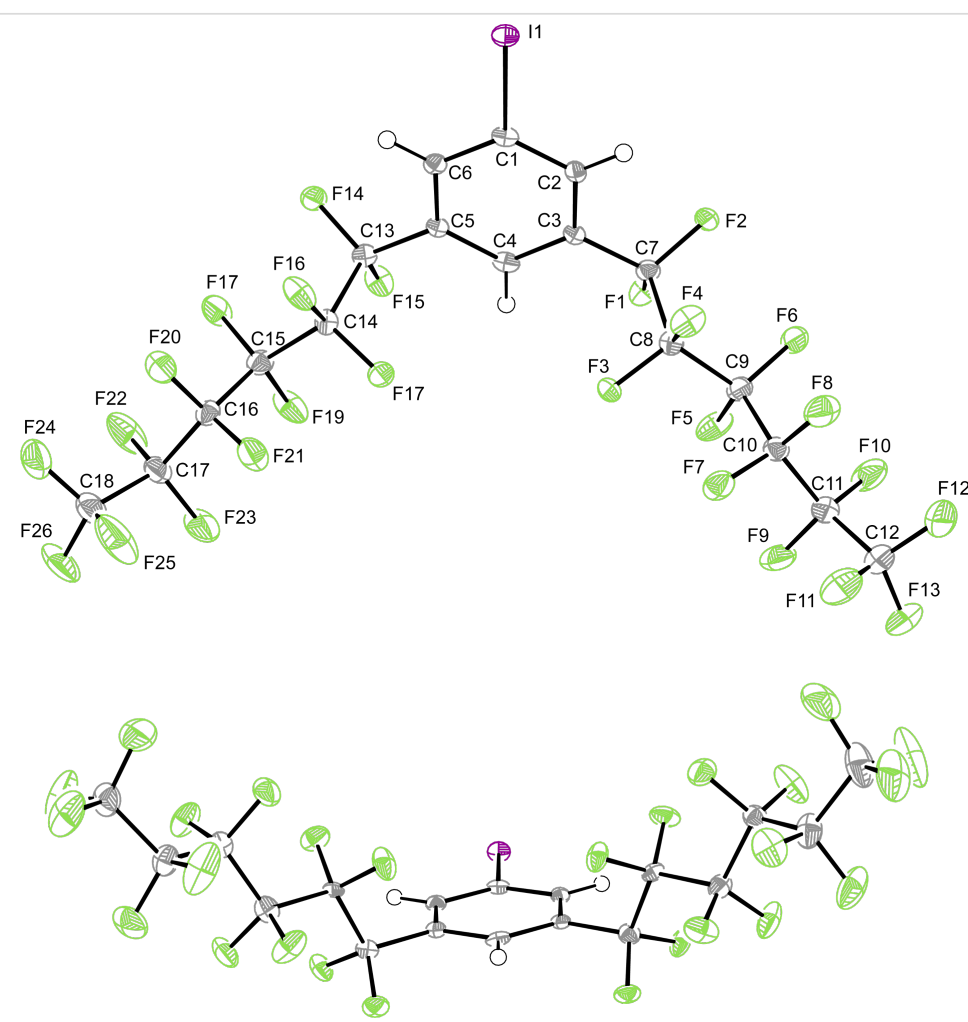

Figure 2: Two views of the molecular structure of 1,3,5-( $\left(\mathrm{R}_{\mathrm{f} 6}\right)_{2} \mathrm{C}_{6} \mathrm{H}_{3}$ I with thermal ellipsoids at the $50 \%$ probability level. Key bond lengths $(\AA)$ and angles $\left({ }^{\circ}\right.$ ): C1-I1 2.099(3), C1-C2 1.391(4), C2-C3 1.386(4), C3-C4 1.393(4), C4-C5 1.387(4), C5-C6 1.393(4), C6-C1 1.394(4), C3-C7 1.501(4), C5-C13 1.508(4), average of 10 CF-CF 1.545(5), I1-C1-C2 119.0(2), C1-C2-C3 118.8(3), C2-C3-C4 121.0(3), C3-C4-C5 119.2(3), C4-C5-C6 121.1(3), C5-C6-C1 118.5(3), C6-C1-C2 121.4(3), C6-C1-I1 119.5(2), C2-C3-C7 119.7(2), C4-C3-C7 119.3(2), C4-C5-C13 119.6(2), C6-C5-C13 119.3(2), average of 8 CF-CF-CF 115.0(10).

iodine(III) dichlorides. Aliphatic compounds of the formula $\mathrm{R}_{\mathrm{f} n} \mathrm{ICl}_{2}$ are clearly very unstable with respect to $\mathrm{Cl}_{2}$ loss, although there is literature precedent for their synthesis and isolation from other iodine(III) precursors under exacting low temperature conditions [43]. When an insulating methylene group is introduced between the fluorous moiety and the $\mathrm{ICl}_{2}$ group, the situation improves. Compounds of the formula $\mathrm{R}_{\mathrm{f} n} \mathrm{CH}_{2} \mathrm{ICl}_{2}$ can generally be isolated, although they are somewhat labile towards $\mathrm{Cl}_{2}$ loss. In contrast, efforts to prepare the ethereal systems $\mathrm{R}_{\mathrm{fO} x} \mathrm{CH}_{2} \mathrm{ICl}_{2}$ by the chlorination of $\mathrm{R}_{\mathrm{fO} x} \mathrm{CH}_{2} \mathrm{I}$ have been unsuccessful. This poses a conundrum with respect to the DFT calculations; they seemingly possess sufficient Lewis basicity (Figure 4), but there appears to be a kinetic barrier.

In contrast, fluorous aromatic iodine(III) dichlorides bearing a single perfluoroalkyl group, $\mathrm{R}_{\mathrm{f} n} \mathrm{C}_{6} \mathrm{H}_{4} \mathrm{ICl}_{2}$, are easily isolated in analytically pure form (Scheme 5), although they are still subject to slow $\mathrm{Cl}_{2}$ loss in solution (Figure $\mathrm{S} 1$, Supporting Information File 1). However, it has not yet proved possible to quantitatively generate analogs with two perfluoroalkyl groups by chlorinations of iodine(I) precursors (Scheme 6, top); $75-80 \%$ conversions are the maximum realized to date. In contrast, chlorinations of the doubly substituted substrates
$\left(\mathrm{R}_{\mathrm{f} n}\left(\mathrm{CH}_{2}\right)_{m}\right)_{2} \mathrm{C}_{6} \mathrm{H}_{3} \mathrm{I}(m=2,3)$ go to completion, as exemplified in Scheme 1 (bottom) and Scheme 6 (bottom). The intervening methylene groups partially insulate the iodine atoms from the electron-withdrawing perfluoroalkyl segments, enhancing Lewis basicities.

However, it has not yet proved possible to access related compounds with three $\mathrm{R}_{\mathrm{f} n}\left(\mathrm{CH}_{2}\right)_{m}$ groups, at least when two of them are ortho to the iodine atom, as exemplified by $\mathbf{V}$ in Scheme 1 [17]. To probe this point, the DFT calculations were extended to the $\mathrm{R}_{\mathrm{f} 6}$ homologs of the precursors of the three aryliodine(III) dichlorides in Scheme 1. These correspond to VII, VIII, and IX in Scheme 7 (top). The $\Delta G$ values obtained were $-3.40,-3.75$, and $-4.15 \mathrm{kcal} / \mathrm{mol}$, respectively. Thus, the third $\mathrm{R}_{\mathrm{f} n}\left(\mathrm{CH}_{2}\right)_{3}$ substituent enhances the exergonicity of $\mathrm{Cl}_{2}$ addition. Hence, the failure to observe a reaction must represent a kinetic phenomenon. A second "ladder", augmented with the additional alkyl and aryl iodides analyzed in the discussion section, is provided in Figure S3 (Supporting Information File 1).

Interestingly, isodesmic reactions corresponding to Equation 2 in the preceding section can actually be carried out. For example, $\mathrm{Cl}_{2}$ can be transferred from the fluorous aliphatic 


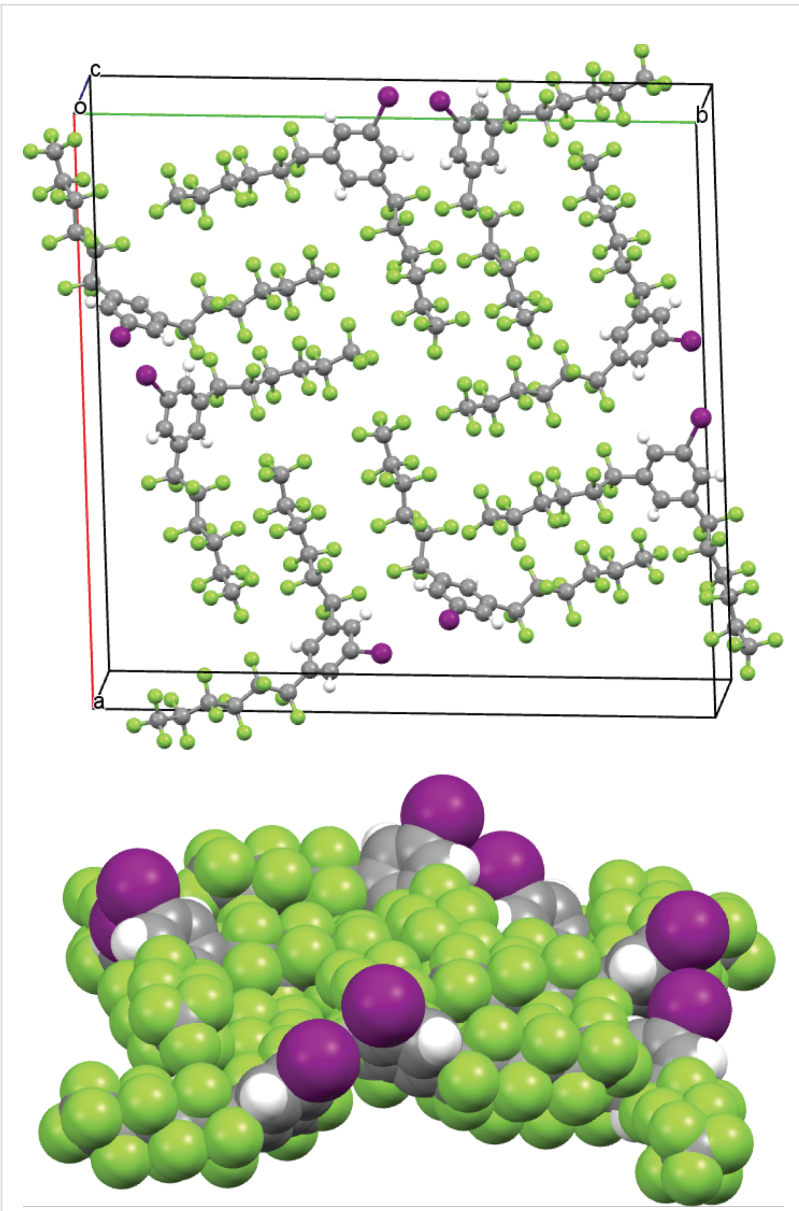

Figure 3: Ball-and-stick and space filling representations of the unit cell of $1,3,5-\left(\mathrm{R}_{\mathrm{f} 6}\right)_{2} \mathrm{C}_{6} \mathrm{H}_{3} \mathrm{l}$.

iodine(III) dichloride $\mathrm{R}_{\mathrm{f} 1} \mathrm{CH}_{2} \mathrm{ICl}_{2}\left(\mathrm{CF}_{3} \mathrm{CH}_{2} \mathrm{ICl}_{2}\right)$ to phenyl iodide as shown in Scheme 7 (middle) [52]. The $\Delta G$ value for the addition of $\mathrm{Cl}_{2}$ to phenyl iodide is computed to be $-3.86 \mathrm{kcal} / \mathrm{mol}$, as compared to $-0.72 \mathrm{kcal} / \mathrm{mol}$ for $\mathrm{R}_{\mathrm{f} 1} \mathrm{CH}_{2} \mathrm{I}$. Curiously, the introduction of two $\mathrm{R}_{\mathrm{f} n}\left(\mathrm{CH}_{2}\right)_{3}$ substituents that are ortho/para or meta/para to iodine is thermodynamically deactivating for $\mathrm{Cl}_{2}$ addition (VII/III and VIII/IV; -3.40 to $-3.75 \mathrm{kcal} / \mathrm{mol})$, whereas the introduction of three that are ortho/para/ortho is activating (IX/V; $-4.15 \mathrm{kcal} / \mathrm{mol})$ but kinetically inhibiting for steric reasons.

As noted in the introduction, a long-standing goal has been to realize highly fluorophilic aliphatic and aromatic iodine(I) compounds and iodine(III) dichlorides. The preceding results raise the question, "quo vadis?" When the compounds $\mathrm{R}_{\mathrm{f} n} \mathrm{CH}_{2} \mathrm{I}$ and $\mathrm{R}_{\mathrm{f} n} \mathrm{CH}_{2} \mathrm{ICl}_{2}$ reach $n=15$ (Scheme 2), they are close to approaching a practical solubility limit, although the former gives a highly biased $\mathrm{CF}_{3} \mathrm{C}_{6} \mathrm{~F}_{11}$ /toluene liquid/liquid partition coefficient. Branched analogs may be more tractable. However, DFT calculations show that chlorinations of substrates such as

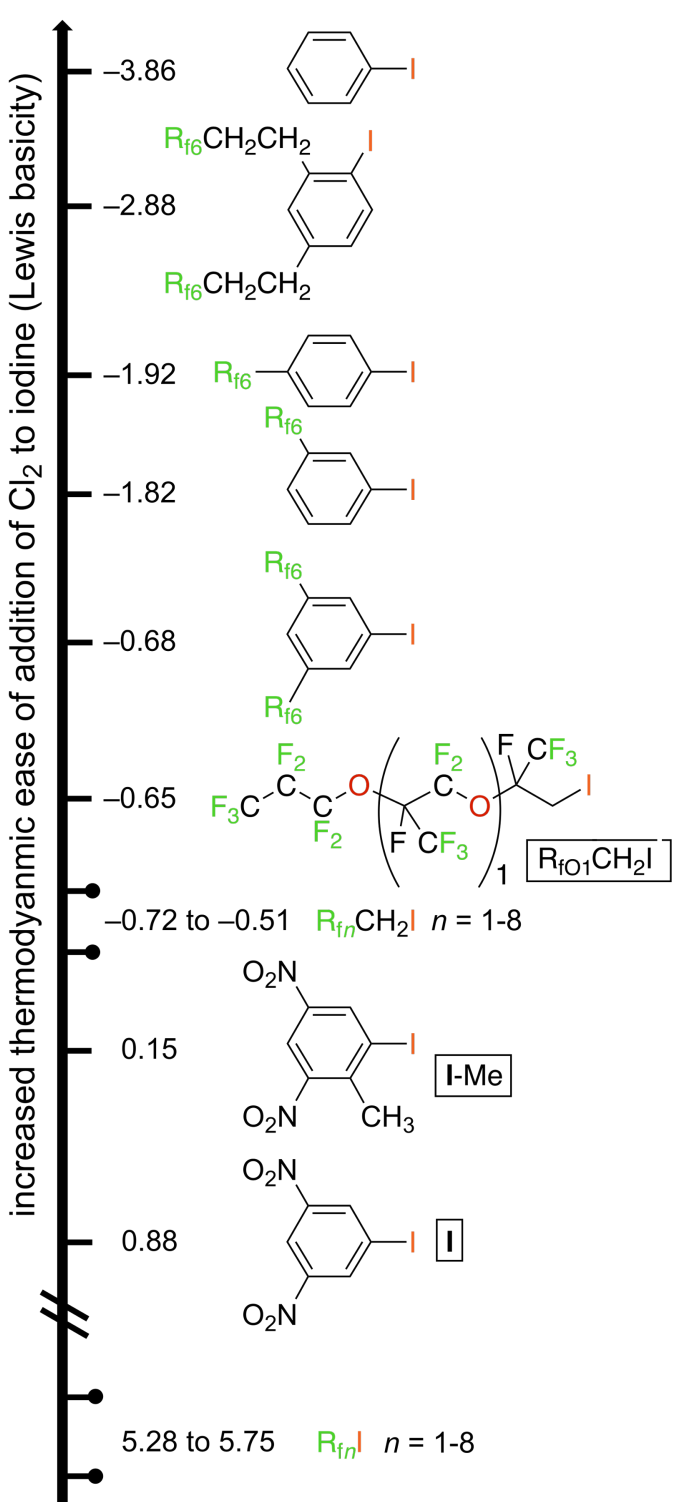

Figure 4: Free energies of chlorination of relevant aryl and alkyl iodides to the corresponding iodine(III) dichlorides in the gas phase ( $\mathrm{kcal} / \mathrm{mol}$ ), presented in a ladder format (each iodide is more Lewis basic than that shown below it).

$\left(\mathrm{R}_{\mathrm{f} n}\right)_{3} \mathrm{CCH}_{2} \mathrm{I} \mathbf{X}$ (Scheme 7) would be strongly endergonic $(\Delta G=3.36 \mathrm{kcal} / \mathrm{mol}, n=6)$. Related species, such as (1) $\left(\mathrm{R}_{\mathrm{f} n}\right)_{3} \mathrm{CCF}_{2} \mathrm{CF}_{2} \mathrm{CH}_{2} \mathrm{I}$, which features a more remote branch site, or (2) $\left(\mathrm{R}_{\mathrm{f} n} \mathrm{CH}_{2}\right)_{3} \mathrm{CCH}_{2} \mathrm{I}$, which features additional insulating methylene groups, would be more likely to give stabile iodine(III) dichlorides. Nonetheless, these types of species have never been described in the literature. Silicon has been used as a locus for branching, as exemplified by a variety of highly fluorophilic compounds of the formula $\left(\mathrm{R}_{\mathrm{f} n} \mathrm{CH}_{2} \mathrm{CH}_{2}\right)_{3} \mathrm{SiZ}$ (see XI in Scheme 7, $\left.\mathrm{Z}=4-\mathrm{C}_{6} \mathrm{H}_{5} \mathrm{X}[53,54]\right)$. However, these feature silicon-carbon and $\mathrm{sp}^{3}$ carbon-hydrogen bonds that may be sensitive towards $\mathrm{Cl}_{2}$. 


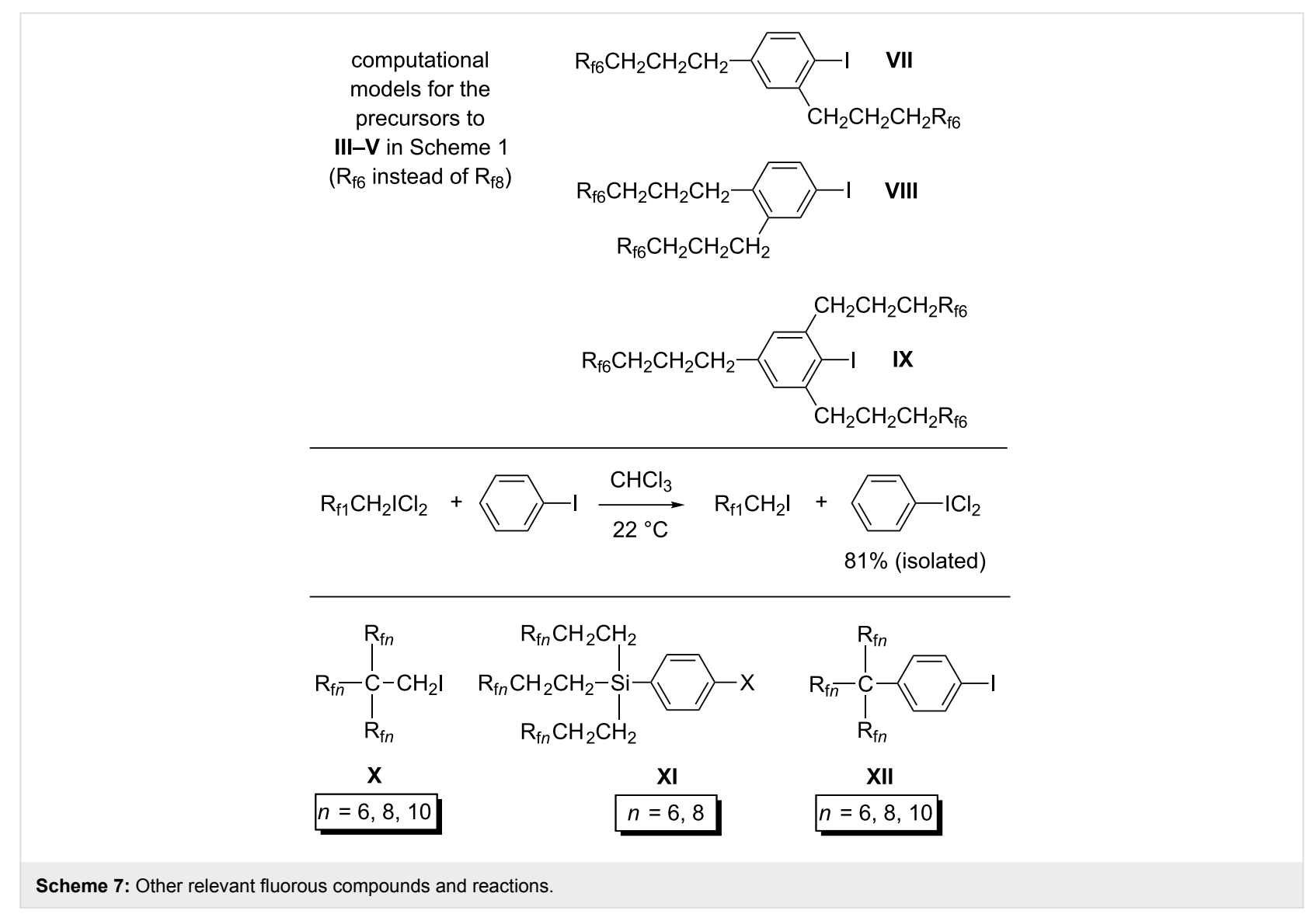

The fluorous aryl iodides that are precursors to III and IV have rather modest fluorophilicities $\left(\mathrm{CF}_{3} \mathrm{C}_{6} \mathrm{~F}_{11}\right.$ /toluene partition coefficients (69.5-74.7):(30.5-25.3) [16]), and simply lengthening the $\mathrm{R}_{\mathrm{f} 8}$ segments to $\mathrm{R}_{\mathrm{f} 10}$ or even longer is unlikely to achieve biases of $>99:<1$. The same goes for $1,2,4-$ $\left(\mathrm{R}_{\mathrm{f} 8} \mathrm{CH}_{2} \mathrm{CH}_{2}\right)_{2} \mathrm{C}_{6} \mathrm{H}_{3} \mathrm{I}$ in Scheme 6. Accordingly, we suggest that branched fluorous aryl iodides of the formula $\left(\mathrm{R}_{\mathrm{fn}}\right)_{3} \mathrm{CC}_{6} \mathrm{H}_{4} \mathrm{I}$ (XII, Scheme 7) have particular promise. DFT calculations establish exergonic chlorinations, with $\Delta G$ values of -1.93 and $-1.59 \mathrm{kcal} / \mathrm{mol}$ for $n=6$ and 8 . This implies that the corresponding iodine(III) dichlorides should have good stabilities, equal to or better than those of $1,3-$ and $1,4-\mathrm{R}_{\mathrm{f} 6} \mathrm{C}_{6} \mathrm{H}_{4} \mathrm{ICl}_{2}$ in Scheme 5. However, this represents a currently unknown type of compound, and the synthesis is potentially challenging.

The following analysis of the crystal structure of 1,3,5$\left(\mathrm{R}_{\mathrm{f} 6}\right)_{2} \mathrm{C}_{6} \mathrm{H}_{3} \mathrm{I}$ is kept brief, as this compound crystallizes in the same space group and crystal system (I4, tetragonal) as the corresponding bromide $1,3,5-\left(\mathrm{R}_{\mathrm{f} 6}\right)_{2} \mathrm{C}_{6} \mathrm{H}_{3} \mathrm{Br}$ reported earlier [48] The unit cell dimensions of the latter are virtually identical, with the cell volume ca. $1.5 \%$ lower $(4851.7(4)$ vs 4920.1(3) $\AA^{3}$ ), apropos to the smaller bromine atom. The space group is both chiral and polar, and the unit cell dimensions of both compounds feature $c$ values $(5.5976(2)-5.5624 \AA)$ that are much smaller than the $a$ and $b$ values (29.6474(9)-29.5335(13) §). As noted earlier and illustrated in Figure 2 (bottom), the sixteen perfluorohexyl groups associated with the eight molecules in the unit cell lie roughly in the $a / b$ plane. They largely segregate, as seen for most fluorous molecules $[44,51,55,56]$, into fluorous domains.

The eight arene rings in the unit cell tilt distinctly out of the $a / b$ plane (average angle $49.1^{\circ}$ ). Furthermore, the eight iodine atoms are oriented on the same "side" or $a / b$ face of the unit cell. In the neighboring unit cell that adjoins the $a / b$ face, the iodine atoms are found on the opposite side ( $c$ direction). This represents the molecular basis for the polar nature of the crystal. Also, the $\mathrm{C}-\mathrm{C}-\mathrm{C}-\mathrm{C}$ and $\mathrm{F}-\mathrm{C}-\mathrm{C}-\mathrm{F}$ segments in the perfluorohexyl groups do not exhibit the idealized antiperiplanar and gauche conformations associated with saturated alkanes. Rather, the torsion angles for the roughly anti linkages average $164.4(1.6)^{\circ}$ and $166.0(3.6)^{\circ}$, respectively. This leads to helical motifs as shown in Figure 5, which are furthermore reproduced by the computations. The basis for this deviation, as well as a more detailed presentation of the torsional relationships, is provided elsewhere [57-59]. In a given molecule, the $\mathrm{C}_{6} \mathrm{~F}_{13}$ groups exhibit opposite helical chiralities (see Figure S2, Supporting Information File 1), affording a meso stereoisomer. 


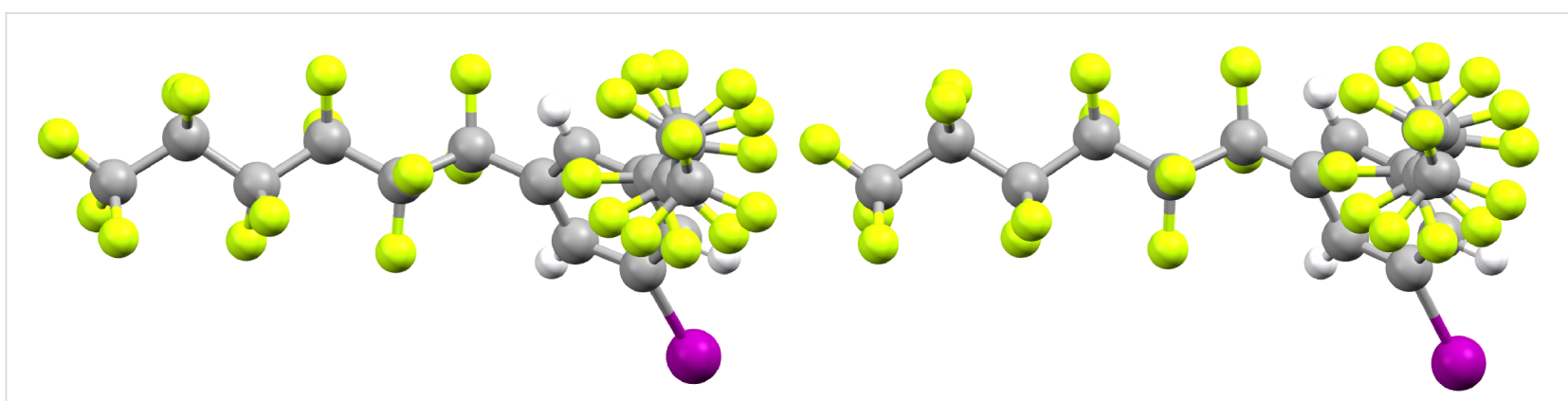

Figure 5: Views of the helical motif of the perfluorohexyl segments in crystalline $1,3,5-\left(\mathrm{R}_{\mathrm{f} 6}\right)_{2} \mathrm{C}_{6} \mathrm{H}_{3} \mathrm{I}$ (left) and the structure computed by DFT calculations (right).

Finally, attempts have been made to extend the preceding chemistry in several directions. In screening experiments, all of the fluorous iodine(III) dichlorides assayed, as well as $\mathrm{PhICl}_{2}$, were competent for the free radical chlorination of methane [25]. Under certain conditions, uncommon selectivities were apparent, but the fluorophilicities of the dichlorides or precursor iodides studied were insufficient for certain target recycling strategies. As discussed above, it is not clear how to meet these challenges at this time, although the couple $\mathrm{R}_{\mathrm{f} 13} \mathrm{CH}_{2} \mathrm{ICl}_{2} /$ $\mathrm{R}_{\mathrm{f} 13} \mathrm{CH}_{2} \mathrm{I}$ would be one of several with promise. Regardless, the fluorous iodides reported herein have numerous other uses, some of which will be communicated in the near future [23].

\section{Conclusion}

The preceding experimental and computational data have established a strong correlation between iodine atom Lewis basicity and the feasibility of oxidizing fluorous and non-fluorous aliphatic and aromatic iodides to the corresponding iodine(III) dichlorides. Although a few surprises are noted, these are attributed to special phenomena that can drive equilibria, such as precipitation (e.g., the conversion of I-Me to II-Me in Scheme 1), or kinetic barriers (inertness of $\mathrm{R}_{\mathrm{fOx}} \mathrm{CH}_{2} \mathrm{I}$ in Scheme 3 or the precursor to $\mathbf{V}$ in Scheme 1). With the fluorous iodides, the extent of chlorination generally provides a measure of the degree to which the electron-withdrawing perfluoroalkyl or perfluoroether segments are insulated from the Lewis basic site.

\section{Experimental}

Five syntheses that are representative of the types of transformations in this study are detailed in the main article. The remaining preparations are described in Supporting Information File 1, together with data on the solvents, starting materials, and instrumentation employed.

$\mathbf{R}_{\mathbf{f 1 1}} \mathbf{C H}_{\mathbf{2}}$ OTf. A Schlenk flask was flame dried, allowed to cool, charged with $\mathrm{R}_{\mathrm{f} 11} \mathrm{CH}_{2} \mathrm{OH}(5.10 \mathrm{~g}, 8.52 \mathrm{mmol})$ and anhydrous $\mathrm{CF}_{3} \mathrm{C}_{6} \mathrm{H}_{5}(50 \mathrm{~mL})$ under a $\mathrm{N}_{2}$ flow, capped, and placed in an ice bath. Then pyridine $(1.0 \mathrm{~mL}, 1.0 \mathrm{~g}, 13 \mathrm{mmol})$ and (after $30 \mathrm{~min}$ ) $\mathrm{Tf}_{2} \mathrm{O}(3.0 \mathrm{~mL}, 5.3 \mathrm{~g}, 14 \mathrm{mmol})$ were added dropwise by syringe with stirring. The ice bath was allowed to warm to room temperature. After $16 \mathrm{~h}, \mathrm{H}_{2} \mathrm{O}(60 \mathrm{~mL})$ was added. After $30 \mathrm{~min}$, the organic phase was separated and dried $\left(\mathrm{MgSO}_{4}\right)$. The solvent was removed by rotary evaporation. The residue was dissolved in petroleum ether/ethyl acetate $(4: 1 \mathrm{v} / \mathrm{v})$. The solution was filtered through a silica pad $(3 \times 5 \mathrm{~cm})$ and the solvent was removed by rotary evaporation to give $\mathrm{R}_{\mathrm{f} 11} \mathrm{CH}_{2} \mathrm{OTf}$ as a white solid (3.82 g, $5.21 \mathrm{mmol}, 61 \%), \mathrm{mp} \mathrm{77.2-79.9}{ }^{\circ} \mathrm{C}$ (capillary). Anal. calcd for $\mathrm{C}_{13} \mathrm{H}_{2} \mathrm{~F}_{26} \mathrm{O}_{3} \mathrm{~S}: \mathrm{C}, 21.33 ; \mathrm{H}, 0.28 ; \mathrm{F}$, 67.46; S, 4.38; found: C, 21.44; H, 0.31; F, 67.21; S, 4.15; ${ }^{1} \mathrm{H}$ NMR $\left(500 \mathrm{MHz}\right.$, acetone- $\left.d_{6}\right) \delta 5.55\left(\mathrm{t},{ }^{3} J_{\mathrm{HF}}=13 \mathrm{~Hz}, 2 \mathrm{H}\right.$, $\left.\mathrm{CH}_{2}\right) ;{ }^{19} \mathrm{~F}\left\{{ }^{1} \mathrm{H}\right\}$ NMR $\left(470 \mathrm{MHz}\right.$, acetone- $\left.d_{6}\right) \delta-75.5(\mathrm{~s}, 3 \mathrm{~F}$, $\left.\mathrm{SO}_{2} \mathrm{CF}_{3}\right),-81.7\left(\mathrm{t},{ }^{4} J_{\mathrm{FF}}=10 \mathrm{~Hz}\right.$ [60-62], 3F, $\left.\mathrm{CF}_{3}\right),-120.2(\mathrm{~m}$, $\left.2 \mathrm{~F}, \mathrm{CF}_{2}\right),-122.2\left(\mathrm{~m}, 12 \mathrm{~F}, 6 \mathrm{CF}_{2}\right),-123.2\left(\mathrm{~m}, 4 \mathrm{~F}, 2 \mathrm{CF}_{2}\right),-126.7$ $\left(\mathrm{m}, 2 \mathrm{~F}, \mathrm{CF}_{2}\right) ;{ }^{13} \mathrm{C}\left\{{ }^{1} \mathrm{H}\right\}$ NMR (125 MHz, acetone- $d_{6}$, partial) $\delta 70.0\left(\mathrm{t},{ }^{2} J_{\mathrm{CF}}=28 \mathrm{~Hz}, \mathrm{CH}_{2}\right.$ ); IR (powder film, $\mathrm{cm}^{-1}$ ): 2924 (w), $2855(\mathrm{w}), 1418(\mathrm{~m}), 1202$ (s), 1140 (s), 1103 (w), 1023 (m), $854(\mathrm{~m}), 822(\mathrm{~m})$.

$\mathbf{R}_{\mathbf{f 1 1}} \mathbf{C H}_{2}$ I. A round bottom flask was charged with $\mathrm{R}_{\mathrm{f} 11} \mathrm{CH}_{2} \mathrm{OTf}$ (3.01 g, $4.11 \mathrm{mmol}$ ), NaI (10.2 g, $68.0 \mathrm{mmol}$ ), and acetone $(30 \mathrm{~mL})$, and fitted with a condenser. The flask was placed in a $75^{\circ} \mathrm{C}$ oil bath and the mixture was stirred. After $1 \mathrm{~d}$, the bath was removed and the mixture was allowed to cool. The solvent was removed by rotary evaporation. Then $\mathrm{Et}_{2} \mathrm{O}(50 \mathrm{~mL})$ and $\mathrm{H}_{2} \mathrm{O}(40 \mathrm{~mL})$ were added with stirring. After $5 \mathrm{~min}$, the dark brown organic phase was separated, washed with saturated aqueous $\mathrm{Na}_{2} \mathrm{~S}_{2} \mathrm{O}_{3}$ until it became colorless, and dried $\left(\mathrm{Na}_{2} \mathrm{SO}_{4}\right)$. The solvent was removed by rotary evaporation and the residue was dissolved in hexanes/ethyl acetate $(20: 1 \mathrm{v} / \mathrm{v})$. The solution was kept at $-35{ }^{\circ} \mathrm{C}$ until a precipitate formed. The solid was collected by filtration and washed with cold hexanes to give $\mathrm{R}_{\mathrm{f} 11} \mathrm{CH}_{2} \mathrm{I}$ as a white solid (2.00 g, $2.82 \mathrm{mmol}, 69 \%$ ), $\mathrm{mp}$ (capillary): $97.8-98.2{ }^{\circ} \mathrm{C}$. Anal. calcd for $\mathrm{C}_{12} \mathrm{H}_{2} \mathrm{~F}_{23} \mathrm{I}$ : C, 20.30; H, 0.28; F, 61.54; I, 17.87; found: C, 20.20; H, 0.16; F, 61.29; I, $17.68 ;{ }^{1} \mathrm{H}$ NMR $\left(500 \mathrm{MHz}\right.$, acetone- $\left.d_{6}\right) \delta 4.06\left(\mathrm{t},{ }^{3} J_{\mathrm{HF}}=19 \mathrm{~Hz}\right.$, 
$\left.2 \mathrm{H}, \mathrm{CH}_{2}\right) ;{ }^{19} \mathrm{~F}\left\{{ }^{1} \mathrm{H}\right\}$ NMR $\left(470 \mathrm{MHz}\right.$, acetone- $\left.d_{6}\right) \delta-81.6(\mathrm{t}$, $\left.{ }^{4} J_{\mathrm{FF}}=10 \mathrm{~Hz}[60-62], 3 \mathrm{~F}, \mathrm{CF}_{3}\right),-107.0\left(\mathrm{~m}, 2 \mathrm{~F}, \mathrm{CF}_{2}\right),-122.2$ (m, 14F, 7CF $),-123.2\left(\mathrm{~m}, 2 \mathrm{~F}, \mathrm{CF}_{2}\right),-126.7\left(\mathrm{~m}, 2 \mathrm{~F}, \mathrm{CF}_{2}\right)$; ${ }^{13} \mathrm{C}\left\{{ }^{1} \mathrm{H}\right\}$ NMR $\left(125 \mathrm{MHz}\right.$, acetone- $d_{6}$, partial) $\delta-3.8\left(\mathrm{t},{ }^{2} J_{\mathrm{CF}}=\right.$ $25 \mathrm{~Hz}, \mathrm{CH}_{2}$ ); IR (powder film, $\mathrm{cm}^{-1}$ ): 2986 (w), 2874 (w), 1422 (w), 1373 (w), 1348 (w), 1234 (s), 1200 (s), 1140 (s), 1040 (m), $858(\mathrm{~m})$.

$\mathbf{R}_{\mathbf{f 1 1}} \mathbf{C H}_{\mathbf{2}} \mathbf{I C l}_{2}$. A round bottom flask was charged with $\mathrm{R}_{\mathrm{f} 11} \mathrm{CH}_{2} \mathrm{I}(1.01 \mathrm{~g}, 1.42 \mathrm{mmol}), \mathrm{C}_{6} \mathrm{~F}_{6}(1.4 \mathrm{~mL})$, and $\mathrm{CH}_{3} \mathrm{CN}$ $(14 \mathrm{~mL})$ with stirring. Aqueous $\mathrm{NaOCl}(2.5 \% \mathrm{w} / \mathrm{w}, 21 \mathrm{~mL})$ and then conc. $\mathrm{HCl}(10 \mathrm{~mL})$ were slowly added. After $2 \mathrm{~h}$, a pale yellow precipitate began to form. After $5 \mathrm{~h}$, the mixture was filtered. The filter cake was washed with hexane $(10 \mathrm{~mL})$ and air dried (4-5 h) to give $\mathrm{R}_{\mathrm{f} 11} \mathrm{CH}_{2} \mathrm{ICl}_{2}$ as a pale yellow powder (0.90 g, $1.15 \mathrm{mmol}, 81 \%)$, mp $122.1-125.4{ }^{\circ} \mathrm{C}$ (capillary). Anal. calcd for $\mathrm{C}_{12} \mathrm{H}_{2} \mathrm{~F}_{23} \mathrm{Cl}_{2} \mathrm{I}$ : C, 18.46; H, 0.26; F, 55.96; Cl, 9.08; found: C, 16.76; H, 1.16; F, 50.15; Cl, 7.98 [63]; ${ }^{1} \mathrm{H}$ NMR $\left(500 \mathrm{MHz}\right.$, acetone- $\left.d_{6}\right) \delta 5.44\left(\mathrm{t},{ }^{3} J_{\mathrm{HF}}=17 \mathrm{~Hz}, 2 \mathrm{H}, \mathrm{CH}_{2}\right)$; ${ }^{19} \mathrm{~F}\left\{{ }^{1} \mathrm{H}\right\}$ NMR (470 MHz, acetone- $d_{6}$, partial) $\delta-106.7$ (m, 2F, $\mathrm{CF}_{2}$ ); IR (powder film, $\mathrm{cm}^{-1}$ ): $3030(\mathrm{w}), 2970(\mathrm{w}), 1392(\mathrm{w})$, 1373 (w), 1348 (w), 1315 (w), 1202 (s), 1148 (s), 1046 (m), 860 (m).

1,3- $\mathbf{R}_{\mathbf{f 6}} \mathbf{C}_{6} \mathbf{H}_{4}$ I. A Schlenk tube was charged with copper $(1.26 \mathrm{~g}, 20.0 \mathrm{mmol})$ and DMSO $(30 \mathrm{~mL})$ and placed in a $105^{\circ} \mathrm{C}$ oil bath. The mixture was sparged with $\mathrm{N}_{2}$ with stirring (30 $\mathrm{min})$, and 1,3-diiodobenzene (6.60 g, $20.0 \mathrm{mmol})$ was added. After a second sparge, $\mathrm{R}_{\mathrm{f} 6} \mathrm{I}(4.48 \mathrm{~g}, 10.0 \mathrm{mmol})$ was added in portions over 30 min under a $\mathrm{N}_{2}$ flow with stirring. The tube was sealed and placed in a $110^{\circ} \mathrm{C}$ oil bath. After $4 \mathrm{~d}$, the mixture was cooled to room temperature and poured into $\mathrm{H}_{2} \mathrm{O}(100 \mathrm{~mL})$. Then $\mathrm{Et}_{2} \mathrm{O}(100 \mathrm{~mL})$ was added with stirring. After $1 \mathrm{~h}$, the aqueous phase was separated and extracted with $\mathrm{Et}_{2} \mathrm{O}(5 \times 50 \mathrm{~mL})$. The combined organic phases were dried $\left(\mathrm{Na}_{2} \mathrm{SO}_{4}\right)$ and the solvent was removed by rotary evaporation. The residue was dissolved in $\mathrm{CH}_{3} \mathrm{CN}(10 \mathrm{~mL})$. The sample was extracted with perfluorohexane $(5 \times 5 \mathrm{~mL})$. The fluorous layers were combined, concentrated to $2 \mathrm{~mL}$, and extracted with acetone $(5 \times 3 \mathrm{~mL})$. The solvent was removed from the extracts by oil pump vacuum to give $1,3-\mathrm{R}_{\mathrm{f} 6} \mathrm{C}_{6} \mathrm{H}_{4} \mathrm{I}$ as a colorless oil (3.16 g, $6.05 \mathrm{mmol}, 60 \%$ based upon $\mathrm{R}_{\mathrm{f} 6} \mathrm{I}$ ). Anal. calcd for $\mathrm{C}_{12} \mathrm{H}_{4} \mathrm{~F}_{13} \mathrm{I}$ : $\mathrm{C} ; 2$ 27.61; H, 0.77; F, 47.31; found: C, 28.09; $\mathrm{H}$, $0.67 ; \mathrm{F}, 48.59$ [63]. The solvent was removed from the concentrated perfluorohexane extract by oil pump vacuum to give 1,3$\left(\mathrm{R}_{\mathrm{f} 6}\right)_{2} \mathrm{C}_{6} \mathrm{H}_{4}$ as a light yellow oil (1.07 $\left.\mathrm{g}, 1.51 \mathrm{mmol}, 15 \%\right)$ [48]. The ${ }^{1} \mathrm{H}$ NMR spectrum matched those in the literature $[47,48]$. ${ }^{1} \mathrm{H}$ NMR $\left(500 \mathrm{MHz}, \mathrm{CD}_{2} \mathrm{Cl}_{2}\right) \delta 8.01(\mathrm{~s}, 1 \mathrm{H}), 7.96\left(\mathrm{~d},{ }^{3} J_{\mathrm{HH}}=8\right.$ $\mathrm{Hz}, 1 \mathrm{H}), 7.61\left(\mathrm{~d},{ }^{3} J_{\mathrm{HH}}=8 \mathrm{~Hz}, 1 \mathrm{H}\right), 7.26\left(\mathrm{t},{ }^{3} J_{\mathrm{HH}}=8 \mathrm{~Hz}, 1 \mathrm{H}\right)$; ${ }^{19} \mathrm{~F}\left\{{ }^{1} \mathrm{H}\right\}\left(470 \mathrm{MHz}, \mathrm{CD}_{2} \mathrm{Cl}_{2}\right) \delta-82.0\left(\mathrm{t},{ }^{4} J_{\mathrm{FF}}=9 \mathrm{~Hz}[60-62]\right.$, $\left.3 \mathrm{~F}, \mathrm{CF}_{3}\right),-111.7\left(\mathrm{t},{ }^{4} J_{\mathrm{FF}}=15 \mathrm{~Hz}[60-62], 2 \mathrm{~F}, \mathrm{CF}_{2}\right),-122.1(\mathrm{~m}$, $\left.2 \mathrm{~F}, \mathrm{CF}_{2}\right),-122.3\left(\mathrm{~m}, 2 \mathrm{~F}, \mathrm{CF}_{2}\right),-123.5\left(\mathrm{~m}, 2 \mathrm{~F}, \mathrm{CF}_{2}\right),-127.0$ $\left(\mathrm{m}, 2 \mathrm{~F}, \mathrm{CF}_{2}\right) ;{ }^{13} \mathrm{C}\left\{{ }^{1} \mathrm{H},{ }^{19} \mathrm{~F}\right\}\left(125 \mathrm{MHz}, \mathrm{CD}_{2} \mathrm{Cl}_{2}\right) \delta 141.9,136.4$, 130.8, 126.8, $118.0\left(5 \times \mathrm{s}, \mathrm{C}_{6} \mathrm{H}_{4}\right), 116.1,115.8,112.0,111.5$, $111.1,109.3\left(5 \times \mathrm{s}, 5 \mathrm{CF}_{2} / \mathrm{CF}_{3}\right), 94.4(\mathrm{~s}, \mathrm{CI})$.

1,3- $\mathbf{R}_{\mathbf{f 6}} \mathbf{C}_{\mathbf{6}} \mathbf{H}_{\mathbf{4}} \mathbf{I C l}_{\mathbf{2}}$. A round bottom flask was charged 1,3$\mathrm{R}_{\mathrm{f} 6} \mathrm{C}_{6} \mathrm{H}_{4} \mathrm{I}(0.523 \mathrm{~g}, 1.00 \mathrm{mmol}), \mathrm{C}_{6} \mathrm{~F}_{6}(1 \mathrm{~mL})$, and $\mathrm{CH}_{3} \mathrm{CN}$ $(10 \mathrm{~mL})$ with stirring. Aqueous $\mathrm{NaOCl}(2.5 \% \mathrm{w} / \mathrm{w}, 10 \mathrm{~mL})$ followed by conc. $\mathrm{HCl}(10 \mathrm{~mL})$ were slowly added. After $30 \mathrm{~min}$, a pale yellow precipitate began to form. After $3 \mathrm{~h}$, the mixture was filtered. The filter cake was washed with $\mathrm{H}_{2} \mathrm{O}(5 \mathrm{~mL})$ and hexane $(10 \mathrm{~mL})$ and air dried $(2 \mathrm{~d})$ to give $1,3-\mathrm{R}_{\mathrm{f} 6} \mathrm{C}_{6} \mathrm{H}_{4} \mathrm{ICl}_{2}$ as a pale yellow powder $(0.477 \mathrm{~g}, 0.804 \mathrm{mmol}, 80 \%)$. Anal. calcd for $\mathrm{C}_{12} \mathrm{H}_{4} \mathrm{~F}_{13} \mathrm{Cl}_{2} \mathrm{I}$ : C, 24.31; $\mathrm{H}, 0.68 ; \mathrm{F}, 41.65$; found: $\mathrm{C}, 23.89$; $\mathrm{H}, 0.38 ; \mathrm{F}, 49.81$ [63]; ${ }^{1} \mathrm{H}$ NMR (500 MHz, $\left.\mathrm{CDCl}_{3} / \mathrm{C}_{6} \mathrm{~F}_{6}\right) \delta$ $8.54-8.52(\mathrm{~m}, 2 \mathrm{H}), 7.94\left(\mathrm{~d},{ }^{3} J_{\mathrm{HH}}=8 \mathrm{~Hz}, 1 \mathrm{H}\right), 7.79\left(\mathrm{t},{ }^{3} J_{\mathrm{HH}}=8\right.$ $\mathrm{Hz}, 1 \mathrm{H}) ;{ }^{19} \mathrm{~F}\left\{{ }^{1} \mathrm{H}\right\}$ NMR $\left(470 \mathrm{MHz}, \mathrm{CDCl}_{3} / \mathrm{C}_{6} \mathrm{~F}_{6}\right) \delta-82.3(\mathrm{t}$, ${ }^{4} J_{\mathrm{FF}}=9 \mathrm{~Hz}$ [60-62], 3F, $\left.\mathrm{CF}_{3}\right),-112.0\left(\mathrm{t},{ }^{4} J_{\mathrm{FF}}=15 \mathrm{~Hz}\right.$ [60-62], $\left.2 \mathrm{~F}, \mathrm{CF}_{2}\right),-124.4\left(\mathrm{~m}, 4 \mathrm{~F}, 2 \mathrm{CF}_{2}\right),-123.7\left(\mathrm{~m}, 2 \mathrm{~F}, \mathrm{CF}_{2}\right),-127.3$ $\left(\mathrm{m}, 2 \mathrm{~F}, \mathrm{CF}_{2}\right)$.

Partition coefficients. The following is representative. A $20 \mathrm{~mL}$ vial was charged with a $\mathrm{CF}_{3} \mathrm{C}_{6} \mathrm{~F}_{11}$ solution of $\mathrm{R}_{\mathrm{f} n} \mathrm{CH}_{2} \mathrm{I}\left(n=11,15 ; 5.0 \times 10^{-2} \mathrm{M}, 4.0 \mathrm{~mL}\right)$ and toluene $(4.0 \mathrm{~mL})$, capped, and vigorously stirred. After $10 \mathrm{~min}$ at room temperature $\left(24^{\circ} \mathrm{C}\right)$, aliquots were removed from the fluorous $(2.0 \mathrm{~mL})$ and organic $(2.0 \mathrm{~mL})$ phases. The solvent was evaporated from each, and the residues were dried under vacuum. A solution of $\mathrm{Ph}_{2} \mathrm{SiMe}_{2}$ (internal standard; $0.0055 \mathrm{~mL}$ ) in acetone$d_{6} / \mathrm{CF}_{3} \mathrm{C}_{6} \mathrm{H}_{5}(1: 1 \mathrm{v} / \mathrm{v} ; 10.0 \mathrm{~mL})$ was prepared. Each residue was dissolved in $1.00 \mathrm{~mL}$ of this solution and ${ }^{1} \mathrm{H}$ NMR spectra were recorded. The relative peak integrations gave the corresponding partition coefficients.

Crystallography. A solution of 1,3,5-( $\left(\mathrm{R}_{\mathrm{f} 6}\right)_{2} \mathrm{C}_{6} \mathrm{H}_{3} \mathrm{I}$ (ca. $0.05 \mathrm{~g}$ ) in $\mathrm{CHCl}_{3} / \mathrm{C}_{6} \mathrm{~F}_{6}(1.0 \mathrm{~mL}, 4: 1 \mathrm{v} / \mathrm{v})$ in an NMR tube was allowed to concentrate. After $2 \mathrm{~d}$, colorless needles with well defined faces were obtained. Data were collected as outlined in Table 1. Integrated intensity information for each reflection was obtained by reduction of the data frames with the program APEX2 [64]. Data were corrected for Lorentz and polarization factors, and using SADABS [65] for absorption and crystal decay effects. The structure was solved by direct methods using SHELXTL/XS $[66,67]$. Non-hydrogen atoms were refined with anisotropic thermal parameters. Hydrogen atoms were placed in idealized positions and refined using a riding model. The structure was refined (weighted least squares refinement on $F^{2}$ ) to convergence [66-68].

Calculations. Computations were performed with the Gaussian09 program package, employing the ultrafine grid 
$(99,590)$ to enhance accuracy [69]. Geometries were optimized using density functional theory (DFT). The B3LYP [70-72] functional was employed with an all-electron $6-311+G(d, p)[73]$ basis set on all atoms except iodine, which was treated using an effective core potential, SDD [74]. The optimized structures were subjected to frequency calculations (using the same functional and basis set as before) to confirm that all structures were local minima and to obtain the free energies of chlorination (Figure 4 and Table S1, Supporting Information File 1).

\section{Supporting Information}

Full details and product characterization for all the syntheses described in Schemes 2, 3, 5, and 6, information on the solvents, starting materials, and instrumentation employed, and additional spectroscopic, structural, and computational data, including a molecular structure file that can be read by the program Mercury [75] and contains the optimized geometries of all computed structures [76].

\section{Supporting Information File 1}

Experimental section continued.

[http://www.beilstein-journals.org/bjoc/content/ supplementary/1860-5397-13-246-S1.pdf]

\section{Supporting Information File 2}

Molecular structure file.

[http://www.beilstein-journals.org/bjoc/content/ supplementary/1860-5397-13-246-S2.mol2]

\section{Acknowledgements}

The authors thank the Qatar National Research Fund for support (project number 5-848-1-142), the Laboratory for Molecular Simulation and Texas A\&M High Performance Research Computing for resources, Prof. Michael B. Hall and Dr. Lisa M. Pérez for helpful discussions, and Dr. Markus Jurisch for preliminary studies of $\mathrm{R}_{\mathrm{f} 13} \mathrm{CH}_{2} \mathrm{OTf}$ and $\mathrm{R}_{\mathrm{f} 13} \mathrm{CH}_{2} \mathrm{I}$.

\section{ORCID ${ }^{\circledR}$ iDs}

Tathagata Mukherjee - https://orcid.org/0000-0002-6369-8923 Andreas Ehnbom - https://orcid.org/0000-0002-7044-1712 Hassan S. Bazzi - https://orcid.org/0000-0002-5702-0091 John A. Gladysz - https://orcid.org/0000-0002-7012-4872

\section{References}

1. Gladysz, J. A.; Curran, D. P.; Horváth, I. T., Eds. Handbook of Fluorous Chemistry; Wiley-VCH: Weinheim, 2004.

2. Horváth, I. T., Ed. Fluorous, Chemistry. Topics in Current Chemistry; Springer, 2012.

3. Mukherjee, T.; Gladysz, J. A. Aldrichimica Acta 2015, 48, 25-28.
4. As of the submission date of this manuscript, a SciFinder search ( $n \geq 6$ ) showed only 1,4- $\mathrm{R}_{\mathrm{f} 6} \mathrm{C}_{6} \mathrm{H}_{4} \mathrm{l}$ (Hong Kong Chemhere Co.).

5. Kysilka, O.; Rybáčková, M.; Skalický, M.; Kvíčalová, M.; Cvačka, J.; Kvíčala, J. Collect. Czech. Chem. Commun. 2008, 73, 1799-1813. doi:10.1135/cccc20081799

6. Lapčik, J.; Girnello, O.; Ladmiral, V.; Friesen, C. M.; Ameduri, B. Polym. Chem. 2015, 6, 79-96. doi:10.1039/C4PY00965G

7. Dolbier, W. R., Jr. Chem. Rev. 1996, 96, 1557-1584. doi:10.1021/cr941142c

8. Brace, N. O. J. Fluorine Chem. 2001, 108, 147-175. doi:10.1016/S0022-1139(01)00348-7

9. Cowell, A. B.; Tamborski, C. J. Fluorine Chem. 1981, 17, 345-356. doi:10.1016/S0022-1139(00)81780-7

10. Darses, S.; Pucheault, M.; Genêt, J.-P. Eur. J. Org. Chem. 2001, 1121-1128. doi:10.1002/1099-0690(200103)2001:6<1121::AID-EJOC1121>3.0.CO ;2-3

11. Miura, T.; Nakashima, K.; Tada, N.; Itoh, A. Chem. Commun. 2011, 47, 1875-1877. doi:10.1039/C0CC03149F

12. Jiang, D.-F.; Liu, C.; Guo, Y.; Xiao, J.-C.; Chen, Q.-Y. Eur. J. Org. Chem. 2014, 6303-6309. doi:10.1002/ejoc.201402820

13. Alvey, L. J.; Rutherford, D.; Juliette, J. J. J.; Gladysz, J. A. J. Org. Chem. 1998, 63, 6302-6308. doi:10.1021/jo980692y

14. Alvey, L. J.; Meier, R.; Soós, T.; Bernatis, P.; Gladysz, J. A. Eur. J. Inorg. Chem. 2000, 1975-1983. doi:10.1002/1099-0682(200009)2000:9<1975::AID-EJIC1975>3.0.CO; 2-M

15. Wende, M.; Seidel, F.; Gladysz, J. A. J. Fluorine Chem. 2003, 124, 45-54. doi:10.1016/S0022-1139(03)00171-4

16. Rocaboy, C.; Gladysz, J. A. Chem. - Eur. J. 2003, 9, 88-95. doi:10.1002/chem.200390034

17. Podgoršek, A.; Jurisch, M.; Stavber, S.; Zupan, M.; Iskra, J.; Gladysz, J. A. J. Org. Chem. 2009, 74, 3133-3140. doi:10.1021/jo900233h

18. Tesevic, V.; Gladysz, J. A. Green Chem. 2005, 7, 833-836. doi:10.1039/b511951k

19. Tesevic, V.; Gladysz, J. A. J. Org. Chem. 2006, 71, 7433-7440. doi:10.1021/jo0612067

20. Bravo, P., III; Montanari, V.; Resnati, G.; DeMarteau, D. D. J. Org. Chem. 1994, 59, 6093-6094. doi:10.1021/jo00099a048

21. Lion, C. J.; Vasselin, D. A.; Schwalbe, C. H.; Matthews, C. S.; Stevens, M. F. G.; Westwell, A. D. Org. Biomol. Chem. 2005, 3, 3996-4001. doi:10.1039/B510240E

22. Zagulyaeva, A. A.; Yusubov, M. S.; Zhdankin, V. V. J. Org. Chem. 2010, 75, 2119-2122. doi:10.1021/jo902733f

23. Ghosh, S. K.; Gladysz, J. A.; Cummins, C. C. manuscript in preparation.

24. Cossairt, B. M.; Cummins, C. C. New J. Chem. 2010, 34, 1533-1536. doi:10.1039/c0nj00124d

25. Mukherjee, T.; El-Zoghbi, I.; Bazzi, S.; Gladysz, J. A. unpublished results.

26. Banks, D. F.; Huyser, E. S.; Kleinberg, J. J. Org. Chem. 1964, 29 , 3692-3693. doi:10.1021/jo01035a504

27. Tanner, D. D.; van Bostelen, P. B. J. Org. Chem. 1967, 32, 1517-1521. doi:10.1021/jo01280a047

28. Gladysz, J. A. Catalysis Involving Fluorous Phases: Fundamentals and Directions for Greener Methodologies. In Handbook of Green Chemistry; Anastas, P.; Crabtree, R. H., Eds.; Chapter 2 (See section 2.5), Vol. 1: Homogeneous Catalysis; Wiley-VCH: Weinheim, 2009. 
29. Kiss, L. E.; Kövesdi, I.; Rábai, J. J. Fluorine Chem. 2001, 108, 95-109. doi:10.1016/S0022-1139(01)00342-6

30. Rocaboy, C.; Rutherford, D.; Bennett, B. L.; Gladysz, J. A. J. Phys. Org. Chem. 2000, 13, 596-603. doi:10.1002/1099-1395(200010)13:10<596::AID-POC284>3.0.CO;2-M

31. Friedrich, K.; Amann, W.; Fritz, H. Chem. Ber. 1978, 111, 2099-2107. doi:10.1002/cber.19781110605

32. Exner, O. Correlation Analysis in Chemistry. Chapman, N. B.; Shorter, J., Eds.; Chapter 10; Plenum: New York, 1978.

33. Maul, J. J.; Ostrowski, P. J.; Ublacker, G. A.; Linclau, B.; Curran, D. P. Top. Curr. Chem. 1999, 206, 79-105. doi:10.1007/3-540-48664-X_4

34. Tesevic, V.; Gladysz, J. A. Top. Organomet. Chem. 2008, 23, 67-89.

35. Gladysz, J. A.; Emnet, C. Fluorous Solvents and Related Media. In Handbook of Fluorous Chemistry; Gladysz, J. A.; Curran, D. P.; Horváth, I. T., Eds.; Wiley-VCH: Weinheim, 2004; pp 11-23. doi:10.1002/3527603905

36. Zhao, X.-F.; Zhang, C. Synthesis 2007, 551-557. doi:10.1055/s-2007-965889

37. Zhdankin, V. V. Hypervalent lodine Chemistry: Preparation, Structure, and Synthetic Applications of Polyvalent lodine Compounds; Chapter 2; John Wiley \& Sons: New York, 2014.

38. The recipe employed in this work is also a function of location, as $\mathrm{Cl}_{2}$ is very difficult to obtain in Qatar.

39. Hu, X. C.; Andrews, D. Q.; Lindstrom, A. B.; Bruton, T. A.; Schaider, L. A.; Grandjean, P.; Lohmann, R.; Carignan, C. C.; Blum, A.; Balan, S. A.; Higgins, C. P.; Sunderland, E. M. Environ. Sci. Technol. Lett. 2016, 3, 344-350. doi:10.1021/acs.estlett.6b00260 See for recent lead references.

40. Lo, A. S. W.; Horváth, I. T. Green Chem. 2015, 17, 4701-4714. doi:10.1039/C5GC01345C

41. Chu, Q.; Henry, C.; Curran, D. P. Org. Lett. 2008, 10, 2453-2456. doi:10.1021/ol800750q

42. Skalický, M.; Skalická, V.; Paterová, J.; Rybáčková, M.; Kvíčalová, M.; Cvačka, J.; Březinová, A.; Kvíčala, J. Organometallics 2012, 31 , 1524-1532. doi:10.1021/om201062c

43. Minkwitz, R.; Berkei, M. Inorg. Chem. 1999, 38, 5041-5044. doi:10.1021/ic990441n

44. Rocaboy, C.; Hampel, F.; Gladysz, J. A. J. Org. Chem. 2002, 67, 6863-6870. doi:10.1021/jo011173p

45. McLoughlin, V. C. R.; Thrower, J. Tetrahedron 1969, 25, 5921-5940. doi:10.1016/S0040-4020(01)83100-8

46. Ishihara, K.; Kondo, S.; Yamamoto, H. Synlett 2001, 1371-1374. doi:10.1055/s-2001-16788

47. van den Broeke, J.; Deelman, B.-J.; van Koten, G. Tetrahedron Lett. 2001, 42, 8085-8087. doi:10.1016/S0040-4039(01)01716-6

48. Ghosh, S. K.; Ojeda, A. S.; Guerrero-Leal, J.; Bhuvanesh, N.; Gladysz, J. A. Inorg. Chem. 2013, 52, 9369-9378. doi:10.1021/ic400945u

49. Su, H.-L.; Balogh, J.; Al-Hashimi, M.; Seapy, D. G.; Bazzi, H. S.; Gladysz, J. A. Org. Biomol. Chem. 2016, 14, 10058-10069. doi:10.1039/C6OB01980C

50. This formula is potentially ambiguous. For all benzenoid compounds in the paper, any iodine substituent is assigned the 1-position.

51. Guillevic, M.-A.; Arif, A. M.; Gladysz, J. A.; Horváth, I. T. Angew. Chem., Int. Ed. Engl. 1997, 36, 1612-1615. doi:10.1002/anie.199716121

52. Montanari, V.; DesMarteau, D. D.; Pennington, W. T. J. Mol. Struct 2000, 550-551, 337-348. doi:10.1016/S0022-2860(00)00502-0
53. Richter, B.; de Wolf, E.; van Koten, G.; Deelman, B.-J. J. Org. Chem. 2000, 65, 3885-3893. doi:10.1021/jo991548v

54. de Wolf, E.; Riccomagno, E.; de Pater, J. J. M.; Deelman, B.-J.; van Koten, G. J. Comb. Chem. 2004, 6, 363-374. doi:10.1021/cc049959z

55. Corrêa da Costa, R.; Hampel, F.; Gladysz, J. A. Polyhedron 2007, 26, 581-588. doi:10.1016/j.poly.2006.08.015

56. Tuba, R.; Brothers, E. N.; Reibenspies, J. H.; Bazzi, H. S.; Gladysz, J. A. Inorg. Chem. 2012, 51, 9943-9949. doi:10.1021/ic301434g

57. See literature cited within references [55] and [56] and the more recent studies in references [58] and [59].

58. Quarti, C.; Milani, A.; Castiglioni, C. J. Phys. Chem. B 2013, 117, 706-718. doi:10.1021/jp3102145

59. Cormanich, R. A.; O'Hagan, D.; Bühl, M. Angew. Chem., Int. Ed. 2017, 56, 7867-7870. doi:10.1002/anie.201704112

60. The triplets commonly observed for $\mathrm{CF}_{2} \mathrm{CF}_{2} \mathrm{CF}_{3}$ and $\mathrm{CF}_{2} \mathrm{CF}_{2} \mathrm{CF}_{2} \mathrm{X}$ signals have been shown to be four bond and not three bond (vicinal) couplings $[61,62]$

61. White, H. F. Anal. Chem. 1966, 38, 625-626. doi:10.1021/ac60236a025

62. Foris, A. Magn. Reson. Chem. 2004, 42, 534-555. doi:10.1002/mrc. 1368

63. These microanalytical data feature one or more values outside of normally accepted ranges but are presented nonetheless as the best fit obtained to date, and/or to illustrate a point made in the text.

64. APEX2. Program for Data Collection on Area Detectors; BRUKER AXS Inc.: Madison, WI, USA.

65. SADABS, Program for Absorption Correction of Area Detector Frames; Sheldrick, G. M. BRUKER AXS Inc.: Madison, WI, USA.

66. Sheldrick, G. M. Acta Crystallogr., Sect. A: Found. Crystallogr. 2008, 64, 112-122. doi:10.1107/S0108767307043930

67. Sheldrick, G. M. Acta Crystallogr., Sect. C: Struct. Chem. 2015, 71 , 3-8. doi:10.1107/S2053229614024218

68. Dolomanov, O. V.; Bourhis, L. J.; Gildea, R. J.; Howard, J. A. K.; Puschmann, H. J. Appl. Crystallogr. 2009, 42, 339-341. doi:10.1107/S0021889808042726

69. Gaussian 09, Revision D.01; Gaussian, Inc.: Wallingford CT, 2009.

70. Becke, A. D. Phys. Rev. A 1988, 38, 3098-3100. doi:10.1103/PhysRevA.38.3098

71. Becke, A. D. J. Chem. Phys. 1993, 98, 5648-5652. doi:10.1063/1.464913

72. Lee, C.; Yang, W.; Parr, R. G. Phys. Rev. B 1988, 37, 785-789. doi:10.1103/PhysRevB.37.785

73. Hariharan, P. C.; Pople, J. A. Theor. Chim. Acta 1973, 28, 213-222. doi:10.1007/BF00533485

74. Peterson, K. A.; Shepler, B. C.; Figgen, D.; Stoll, H. J. Phys. Chem. A 2006, 110, 13877-13883. doi:10.1021/jp065887।

75. Macrae, C. F.; Bruno, I. J.; Chisholm, J. A.; Edgington, P. R.; McCabe, P.; Pidcock, E.; Rodriguez-Monge, L.; Taylor, R.; van de Streek, J.; Wood, P. A. J. Appl. Crystallogr. 2008, 41, 466-470. doi:10.1107/S0021889807067908

76. Lichtenberger, D. L.; Gladysz, J. A. Organometallics 2014, 33, 835 doi:10.1021/om500109u 


\section{License and Terms}

This is an Open Access article under the terms of the Creative Commons Attribution License

(http://creativecommons.org/licenses/by/4.0), which permits unrestricted use, distribution, and reproduction in any medium, provided the original work is properly cited.

The license is subject to the Beilstein Journal of Organic Chemistry terms and conditions:

(http://www.beilstein-journals.org/bjoc)

The definitive version of this article is the electronic one which can be found at:

doi:10.3762/bjoc. 13.246 